\title{
Review \\ Carbon Nanotubes-Based Hydrogels for Bacterial Eradiation and Wound-Healing Applications
}

\author{
Tejal V. Patil ${ }^{1,2}$, Dinesh K. Patel ${ }^{1}$, Sayan Deb Dutta ${ }^{1}{ }^{(0}$, Keya Ganguly ${ }^{1}$, Aayushi Randhawa ${ }^{3} \mathbb{C}$ \\ and Ki-Taek Lim 1,2,*(i) \\ 1 Department of Biosystems Engineering, Institute of Forest Science, Kangwon National University, \\ Chuncheon 24341, Korea; tejal.patil07@gmail.com (T.V.P.); dbhu10@gmail.com (D.K.P.); \\ sayan91dutta@gmail.com (S.D.D.); gkeya14@gmail.com (K.G.) \\ 2 Interdisciplinary Program in Smart Agriculture, Kangwon National University, Chuncheon 24341, Korea \\ 3 Department of Microbiology \& Biotechnology, Banglore University, Jnana Bharathi Campus, \\ Banglore 560056, India; randhawaaayushi15@gmail.com \\ * Correspondence: ktlim@kangwon.ac.kr
}

Citation: Patil, T.V.; Patel, D.K.; Dutta, S.D.; Ganguly, K.; Randhawa, A.; Lim, K.-T. Carbon

Nanotubes-Based Hydrogels for Bacterial Eradiation and Wound-Healing Applications. Appl. Sci. 2021, 11, 9550. https://doi.org/ 10.3390/app11209550

Academic Editor: Elzbieta Pach

Received: 17 September 2021

Accepted: 6 October 2021

Published: 14 October 2021

Publisher's Note: MDPI stays neutral with regard to jurisdictional claims in published maps and institutional affiliations.

Copyright: (c) 2021 by the authors. Licensee MDPI, Basel, Switzerland. This article is an open access article distributed under the terms and conditions of the Creative Commons Attribution (CC BY) license (https:// creativecommons.org/licenses/by/ $4.0 /)$.

\begin{abstract}
Biocompatible nanomaterials have attracted enormous interest for biomedical applications. Carbonaceous materials, including carbon nanotubes $(\mathrm{CNTs})$, have been widely explored in wound healing and other applications because of their superior physicochemical and potential biomedical properties to the nanoscale level. CNTs-based hydrogels are widely used for wound-healing and antibacterial applications. CNTs-based materials exhibited improved antimicrobial, antibacterial, adhesive, antioxidants, and mechanical properties, which are beneficial for the wound-healing process. This review concisely discussed the preparation of CNTs-based hydrogels and their antibacterial and wound-healing applications. The conductive potential of CNTs and their derivatives is discussed. It has been observed that the conductivity of CNTs is profoundly affected by their structure, temperature, and functionalization. CNTs properties can be easily modified by surface functionalization. CNTs-based composite hydrogels demonstrated superior antibacterial potential to corresponding pure polymer hydrogels. The accelerated wound healing was observed with CNTs-based hydrogels.
\end{abstract}

Keywords: carbon nanotubes (CNTs); conductive hydrogels; antibacterial; wound healing

\section{Introduction}

The annual wound care costs are estimated to be several billion dollars, which constitute approximately 2-3\% total expenditure on health [1]. Wound healing is one of the most complex and essential treatments in the human body. Skin injury also occurs in daily life, where the skin loses its protective action, leading to the formation of a wound in the skin [2]. Multiple cell types are required within the damaged skin layers to accelerate the healing process, such as hemostasis/inflammation, angiogenesis, proliferation, and remodeling. Several therapies are available for the wound-healing process [3]. These therapies include both conventional and modern treatments. Some examples of modern and currently used treatments are stem cell therapy [4], oxygen therapy [5], nitric oxide therapy [6], artificial dressing [7], and growth factor therapy [8]. Comparatively, conventional treatments include using natural substances such as plant extracts, honey, propolis, larvae, etc. [9]. The treatments are effective when the healing materials are fabricated with excellent wound-healing potential. Different materials are developed for this process; still, few reports are available on more effective therapies $[2,10]$. The incorporation of nanomaterials with biocompatible polymers has been an emerging area for wound-healing application. Commonly, two types of approaches are used where nanomaterials either act as drug or vehicle to deliver the drug. Materials such as silver, gold, zinc, gold copper, titanium, and terbium are used in the form of nanoparticles to act as a drug. Whereas, in another approach, nanomaterials are used to deliver antibiotics, growth factors, nucleic acids, and antioxidants [11]. The 
design of effective materials for rapid wound healing is emerging, and nanomaterialsbased hydrogels exhibited an improved healing process $[12,13]$. The utilization of inorganic nanomaterials for biomedical applications is an emerging research field. This research topic received significant attention from the researcher community to develop nanocarrier devices for medical applications. Nanomaterials (NM) are classified into four classes: carbon-based NM, inorganic-based NM, organic-based NM, and composite-based NM [14]. Several studies have investigated the development of inorganic conductive materials in combination with non-conductive polymers to support the proliferation and electro-stimuli responsive cell activities [2]. These materials are mainly carbon-based (CNTs and graphene oxide) and metals, which acquired the potential properties for biomedical applications. Since the last decade, CNTs-based nanomaterials have received significant interest from the scientific community and have been widely studied for broad research topics due to their excellent electrical, electronic, and physicochemical properties [15] for electrode materials, biomedical applications, biosensors, bio imaging, drug delivery, tissue engineering, wound healing, sorption materials, and catalysis [16]. Various CNTs composites and their biological applications are listed in Table 1. CNTs-based materials also exhibited antibacterial properties. Antibacterial materials can kill or suppress the growth of bacteria. CNTs are an allotrope of carbon and have high electrical and thermal conductivity and superior mechanical properties [17].

CNTs-based materials can be produced at a large scale that could be an additional advantage in developing industrial-scale biomedical devices $[17,18]$. Several studies have been conducted to explore the potential of CNTs-based materials in biomedical applications, drug delivery, tissue engineering, cancer therapies, implantable devices such as nanosensors, nanorobotics, antibacterial, and wound dressing $[17,19,20]$. However, there is broad scope for the utilization of CNTs-based materials in other clinical applications. In the wound-healing process, electro-conductive composites of CNTs and non-conductive polymeric materials have been efficiently utilized. The combination of intelligent hydrogels and CNTs was very effective in wound dressing and antibacterial treatment [21,22].

Table 1. List of CNTs-based composites and their biological applications.

\begin{tabular}{llll}
\hline CNT Composite & Highlight & Biological Application & Reference \\
\hline CP@CNT & $\begin{array}{l}\text { Examine CNT as a nanocarrier of } \\
\text { drug CP }\end{array}$ & $\begin{array}{l}\text { Cyclophosphamide, anticancer drug } \\
\text { delivery, reduced side effects }\end{array}$ \\
\hline [23] & $\begin{array}{l}\text { Penetration of functionalized CNT } \\
\text { through cell membrane }\end{array}$ & $\begin{array}{l}\text { Doxorubicin hydrochloride delivery } \\
\text { for cancer treatment }\end{array}$ \\
\hline [24] & $\begin{array}{l}\text { CNT incorporation showed high } \\
\text { mechanical and } \\
\text { tribological properties }\end{array}$ & $\begin{array}{l}\text { Sustained release (up to 429 h) } \\
\text { of gentamicin }\end{array}$ \\
\hline CNT-UHMWPE & $\begin{array}{l}\text { Binding energy of drug to CNT } \\
\text { increased with more } \mathrm{H}_{2} \mathrm{PO}_{4} \text { moeities }\end{array}$ & $\begin{array}{l}\text { Delivery for anti-osteoporosis } \\
\text { zolendronate and risedronate drugs }\end{array}$ \\
\hline [26] & $\begin{array}{l}\text { PDA modified scaffold can adhere } \\
\text { laminin for longer time and promote } \\
\text { neurite outgrowth }\end{array}$ & $\begin{array}{l}\text { Enhancement of PC12 cells for nerve } \\
\text { tissue engineering }\end{array}$ \\
\hline [27] \\
\hline Rh-CNT & $\begin{array}{l}\text { Analysis of gases of lung cancer } \\
\left(\mathrm{C}_{6} \mathrm{H}_{6} \text { and } \mathrm{C}_{6} \mathrm{H}_{7} \mathrm{~N}\right)\end{array}$ & $\begin{array}{l}\text { Biosensor for prediagnosis of } \\
\text { lung cancer }\end{array}$ \\
\hline
\end{tabular}

CP-cyclophosphamide; Alg-alginate; Ch-chitosan; FA-folic acid; UHMWPE-ultra-high molecular weight polyethylene; PLGA-polylactideco-glycolide; PDA-polydopamine; lam-laminin; PC12-adrenal phaeochromocytoma cell line; Rh-rhodium.

Hydrogels belong to the group of biomaterials composed of a cross-linked polymer network to form 3D structures that can hold large proportions of water and retain their primary system even after swelling of the wound [21,29,30]. Nanomaterials-based hydrogels are considered an attractive platform for wound-healing applications [13]. These hydrogels demonstrated superior mechanical strength, antioxidant, antibacterial, electrical, and tissue 
regeneration potentials [31-33]. The physicochemical properties of nanomaterials-based hydrogels are profoundly affected by the surface functionalizations [22]. The appealing properties of multifunctional hydrogel make it a promising candidate for wound healing, antibacterial treatment, and other biomedical applications.

This review describes the preparation of CNTs-based hydrogels and their potential applications for skin dressing and antibacterial. We briefly discussed the functionalizations and conductivity of CNTs. The perspective for the possible future directions in developing CNTs-based hydrogels for wound-healing treatment is also summarized. Figure 1 shows the overview of the review article, which includes types of CNT, properties of CNT hydrogels, and their applications.

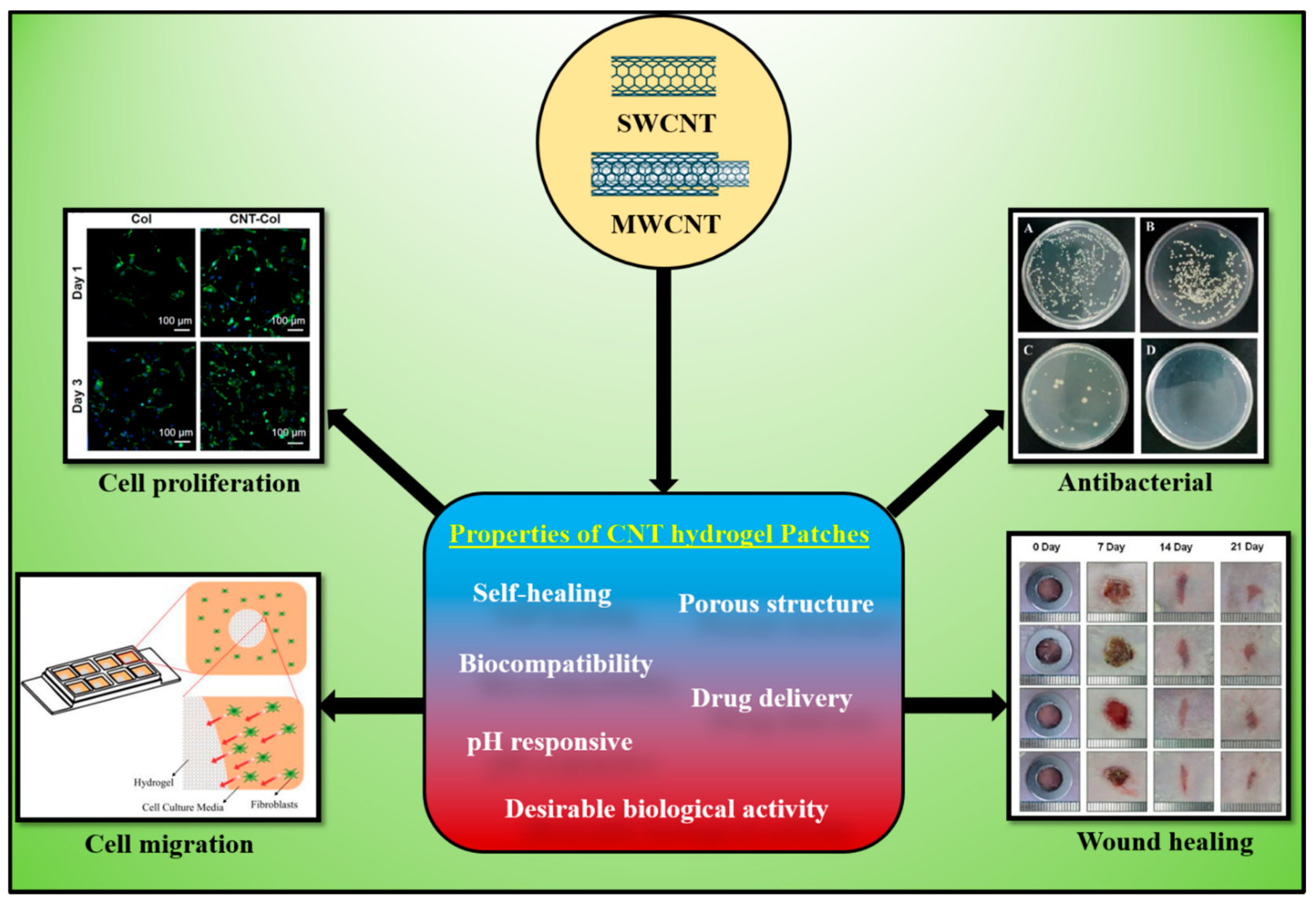

Figure 1. A scheme showing the types of CNT, properties of CNT hydrogel patches, and their application in cell proliferation [34], cell migration [35], antibacterial [36], and wound healing [37].

\section{Conductive Properties of CNTs}

CNTs are an allotropic form of carbon, as mentioned by Sumiolijima in 1991 [38], which have similar properties as graphene. Structurally, CNTs are cylindrical structures composed by the rolling of graphene sheets with $\mathrm{sp}^{2}$ hybridization. Arc discharge, laser ablation, and chemical vapor deposition (CVD) are commonly utilized to prepare CNTs [39]. In arc discharge and laser ablation methods, the carbon sourced was treated at $3000-4000{ }^{\circ} \mathrm{C}$ to generate cylindrical CNTs, whereas the CVD technique involves the pyrolysis of carbon source at a temperature range of $600-1100{ }^{\circ} \mathrm{C}$. The physicochemical properties of the obtained CNTs are widely influenced by synthetic methods [40]. CNTs exhibit remarkable thermal properties due to their structural form and technique of synthesis. The conductivity range of CNTs can vary from 6000 to $0.1 \mathrm{~W} / \mathrm{mK}$ depending upon the single-walled structure and multi-walled structure, respectively [41,42]. The thermal conductivity is due to the collective vibration of atoms, including phonon and electron transfer [43,44]. 
The length of CNTs also affects the conductivity [44,45]. Therefore, the optimization of synthetic parameters is required to obtain a certain level of thermal conductivity [46]. Berber et al., studied molecular dynamics simulation to determine the thermal conductivity ( $\mathrm{k}=6600 \mathrm{~W} / \mathrm{mK}$ ) of CNTs based on Tersoff-Brenner potential, which is similar to a hypothetical isolated graphene monolayer [47]. In comparison, Osman et al., studied the relationship between the physical parameters of CNTs and their thermal conductivity. They examined that the thermal conductivity of single-walled carbon nanotubes (SWCNTs) changes with the temperature. A decrease in the thermal conductivity of armchair $(10,10)$ configured SWCNTs was observed above $400 \mathrm{~K}$, similar to monolayered graphene. The CNTs with similar diameters but different chirality show maximum conductivity at $300 \mathrm{~K}$, and the armchair CNTs have a comparatively sharper peak than zigzag CNTs [48]. Table 2 shows various properties of single-walled carbon nanotubes (SWCNT) and multi-walled carbon nanotubes (MWCNT).

Table 2. Various properties of SWCNT and MWCNT [49].

\begin{tabular}{cccc}
\hline Properties & Units & SWCNT & MWCNT \\
\hline Specific gravity (bulk) & $\mathrm{g} / \mathrm{cm}^{3}$ & $0.8-1.3$ & $1.8-2.6$ \\
Specific area & $\mathrm{m}^{2} / \mathrm{g}$ & $400-900$ & $200-400$ \\
Young's modulus & $\mathrm{Pa}$ & $\approx 1000$ & $\approx 1000$ \\
Tensile strength & $\mathrm{Pa}$ & $3.10^{10}-5.10^{11}$ & $1.10^{10}-15.10^{10}$ \\
Thermal conductivity & $\mathrm{W} / \mathrm{m} . \mathrm{K}$ & $3000-6000$ & $2000-3000$ \\
Electrical conductivity & $\mathrm{S} / \mathrm{cm}$ & $10^{2}-10^{6}$ & $10^{3}-10^{5}$ \\
Thermal stability & ${ }^{\circ} \mathrm{C}$ & $550-650$ & $550-650$ \\
temperature in air & & &
\end{tabular}

\subsection{Single-Walled and Multi-Walled Carbon Nanotubes}

Based on the number of inner layers, CNTs are categorized into single-walled CNTs (SWCNTs) and multi-walled CNTs (MWCNTs) [50,51]. CNTs properties are varied with the number of inner layers. Different types of CNTs are presented in Figure 2. SWCNTs are composed of a single layer of a graphene sheet and have 1-2 $\mathrm{nm}$ diameters. The controlled catalytic conditions are required to obtain the high quality and purity of SWCNTs. Doubled-walled CNTs (DWCNTs) are generated from two distinct CNTs of inner and outer tubes. The diameter of the outer and inner tubes is approximately $2-4 \mathrm{~nm}$ and $1-3 \mathrm{~nm}$, respectively. DWCNTs have similar properties to SWCNTs, including narrow diameter, electrical, and mechanical properties. MWCNTs are comprised of multilayer graphene sheets rolled with a diameter of 2-50 nm; the outer layer dimeters can reach up to $100 \mathrm{~nm}$, and the inner layer diameter is below $1 \mathrm{~nm}$. SWCNTs are classified into structural models such as the Russian doll and Parchment model, depending on the arrangement of the graphene sheet in the concentric cylinder [52]. MWCNTs have defects in their structure, which favor the surface functionalizations, and these defects are increased with increasing the number of graphene sheets rolled up in MWCNTs. MWCNTs are considered potential materials for biomedical applications because of their excellent chemical, thermal, mechanical, electrical, and variable structural properties and functionalities. Additionally, CNTs show semiconducting and superconducting electron transport properties. The biocompatibility, antimicrobial, and antibacterial properties of CNTs are moderately attractive for their use in wound dressing and antibacterial treatment [13]. 


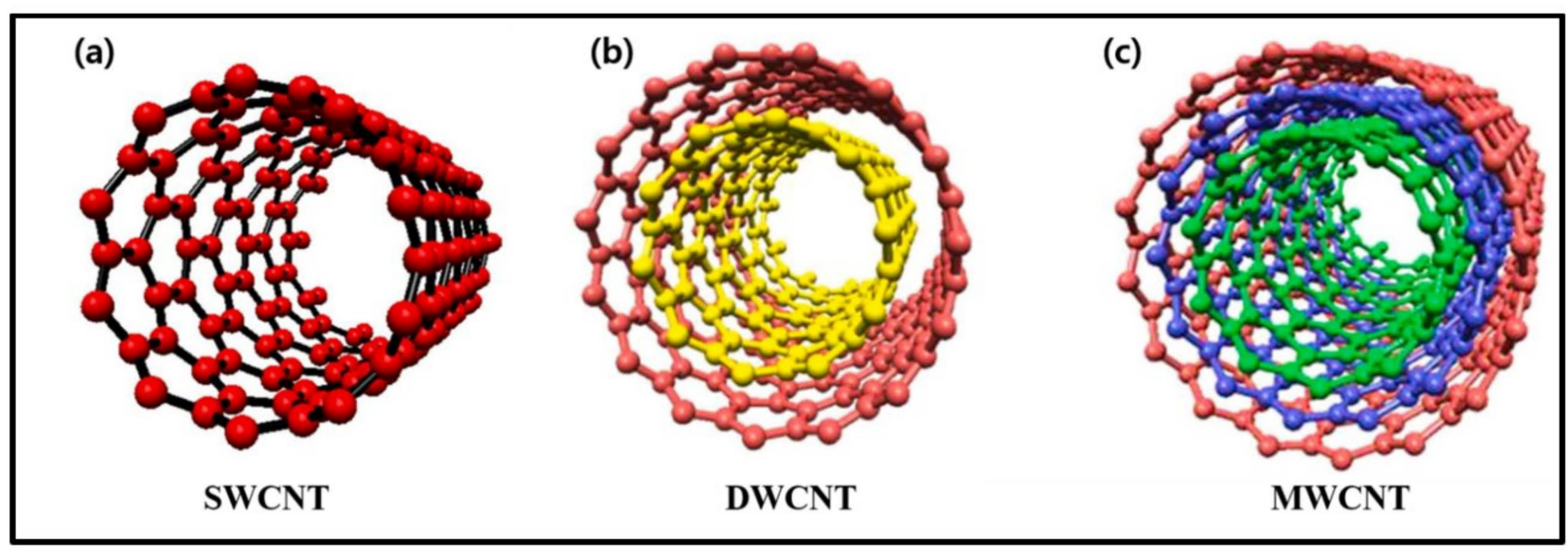

Figure 2. Surface and internal view of (a) single-walled CNTs, (b) double-walled CNTs, and (c) multi-walled CNTs [51].

\subsection{Functionalization of CNTs}

Nanoparticles and their structure with intrinsic chemical compositions would enhance the surface properties such as variable charge, dispersion, dissolutions, hydrophilicity, hydrophobicity, etc. Many studies and techniques are available for the functionalization of CNTs materials [53-55]. The functionalization of CNTs can be categorized as covalentand non-covalent strategies [51]. The covalent modification adds chemical bonds on CNTs by chemical reactions and conjugates hydrophilic molecules or polymers, which increases the solubility of CNTs. Whereas, in non-covalent modification, the hydrophobic behavior of CNTs is used for coating amphiphilic molecules. Thus, the desirable functionalization of CNTs is not a difficult task, which is beneficial for desirable biological or biomedicine feasibility $[17,50]$. The covalent functionalization generates more hydroxyl and carboxylic groups on the surface of CNTs. The non-covalent functionalization has been performed through the adsorptions of desired moieties, including polymers, proteins, DNA, carbohydrates, and hydrogels with CNTs [20]. Most of these surface modification techniques are helpful for the utilization of functionalized CNTs material in biomedical applications.

The functionalized moieties can be precisely fabricated on CNTs' surface cell receptors that can go through their internalization. Despite the vast advantage of CNTs, some concerns are to be addressed before biomedical applications. These concerns are (i) the purity of CNTs and their structural reproducibility in large scale synthesis, (ii) the physicochemical and structural properties of CNTs are varied significantly vary with synthesis, purification, and functionalization methods, (iii) the co-operation between the biological environment and CNTs are not always predictable and very complex, (iv) the toxicity of CNTs is a most critical issue, which depends on the synthesis methods and modifications, (iv) the design and synthesis of desired CNTs-based material on a large scale, and (v) hydrophobicity [17]. In addition, they suggested functionalization strategies that can help in minimizing systemic toxicity and inflammation. Usually, CNT materials have been utilized to combine with hydrogels (non-conductive polymers) to form electroactive composite dressings for wound-healing treatment [12]. The combination of CNT and hydrogel renders excellent electro-conductive properties in the resultant composites, which can effectively transmit electrical stimulation to the wounded tissue. In addition, these CNTs-hydrogel composites exhibit an antibacterial phenomenon. Hence, this promising combination could effectively heal wounds by activating local cell proliferation and migration.

\section{Development of CNT-Based Conductive Hydrogels}

Hydrogels comprise a 3D cross-linked polymeric network structure, holding a large amount of water and maintaining their form even after swelling. Hydrogels are similar to the extracellular matrix and can mimic the microstructure of native cellular environments and provide a moist environment [21]. It can adsorb the fluid excreting from the wound 
through the porous structure and prevent the growth of anaerobic bacteria by the gaseous exchange phenomenon. It can act as a barrier to prevent bacterial infections and improve epithelization and cell migration into the wound [22,56-60]. Hence, hydrogel materials have been broadly used for wound dressing.Conductive hydrogel has received significant attention for various biomedical applications, including wound dressings, drug delivery, biosensors, bio-imaging, and tissue engineering. The hydrogel conductivity is originated due to the presence of conductive ions and electrons. Naturallyderived biopolymers, such as chitosan, peptides, gelatin, and polyamines, are frequently explored to prepare hydrogels due to their excellent biocompatibility [29]. Recently, Zaho et al., developed injectable antibacterial hydrogels for enhanced skin generation. The injectable hydrogel has certain advantages, such as wound site filling with irregular space, wound adherence, and feasibility toward the insitu encapsulation of bioactive molecules and cells [30]. These hydrogels can be designed with advanced features such as bilayer types to control the infiltration of microbes and moistures and additional antibacterial and antimicrobial properties to protect wound sites from infections and inflammations. Different stimuli-responsive properties can be generated in hydrogel to deliver therapeutic molecules, inhibit bacterial infections, and promote cellular proliferation. Multifunctional hydrogels are an emerging approach. It is the composition of hydrogel constituent materials with or without modification and the incorporation of nanostructures in the hydrogels. These construction strategies improve properties (electrical, mechanical, surface, biocompatibility, and biodegradability) for wound-healing applications [61-65].

Zhang et al., summarized the literature to fabricate different types of hydrogel material with antibacterial agents for wound-healing applications [29]. They included the types of hydrogels and their specific methods of incorporations such as physical combination (incorporation, swelling diffusion, encapsulated with carrier), chemical combinations (chemical bonding, hydrogel with biomedicine activity), and incorporation of photo-assisted antibacterial hydrogels. The physical combination of antimicrobial methods has been considered a straightforward and effective method, in which hydrogel was physically incorporated with antibiotics, biological extracts, antimicrobial peptides, and inorganic nanoparticles. These materials are utilized for wound healing and other biomedical treatments. In chemical combinations, the hydrogel is combined with an antibacterial and antimicrobial agent by chemical treatments. However, these hydrogel derivatives should go through further purification steps before their utilizations. The chemical combination method has been commonly used to synthesize CNT-based hydrogels, and the most common hydrogels are chitosan-based, cationic group-based, polypeptide-based, and halogen-based hydrogels. These hydrogels exhibit strong antibacterial and antimicrobial properties, which are necessary to heal the wound [59] effectively. However, several researchers are developing new hydrogel materials to fulfill their demand in biomedical applications [29,66-69]. The following sections highlight some recent studies and developments of CNT hydrogels for wound healing and antibacterial property.

As discussed before, CNT functionalization with hydrogel is considered a potential hybrid candidate material for multiple applications in biomedical fields. CNT can be incorporated with hydrogels through their covalent and non-covalent functionalization using different treatment (chemical and mechanical) techniques [70]. Recently, Vashist et al., have nicely summarized the studies on developing CNT-based hybrid hydrogel for wound-healing applications [13]. In addition, they addressed most of the design and synthesis strategies for CNT hydrogel mixed materials and their diverse applications in the biomedical field.

CNT hydrogels are associated with most of the properties of hydrogel polymeric networks. Generally, five polymerization techniques such as (i) covalent cross-linking (insitupolymerization), (ii) exsitu polymerization, (iii) physical cross-linking, (iv) polymer grafting, and (v) smart devices enable techniques that are exploited for the synthesis of CNT hydrogel hybrid. In both insitu and exsitu polymerizations (chemical treatment), CNT hydrogel outfits with excellent mechanical strength, a variety of shapes and surfaces, 
excellent yields, and it is easy to control the initial and final composition of hybrid gels into the hybrid [71,72]. These techniques involve the introduction of nanofiller during reactions. In physical cross-linking techniques, hydrogels are physically cross-linked with CNT, which showed a high level of biocompatibility but low mechanical strength. These methods have been employed for the synthesis of CNT-based gelatin hydrogels [73]. The schematic representation for the synthesis of CNTs-based hydrogels is shown in Figure 3.

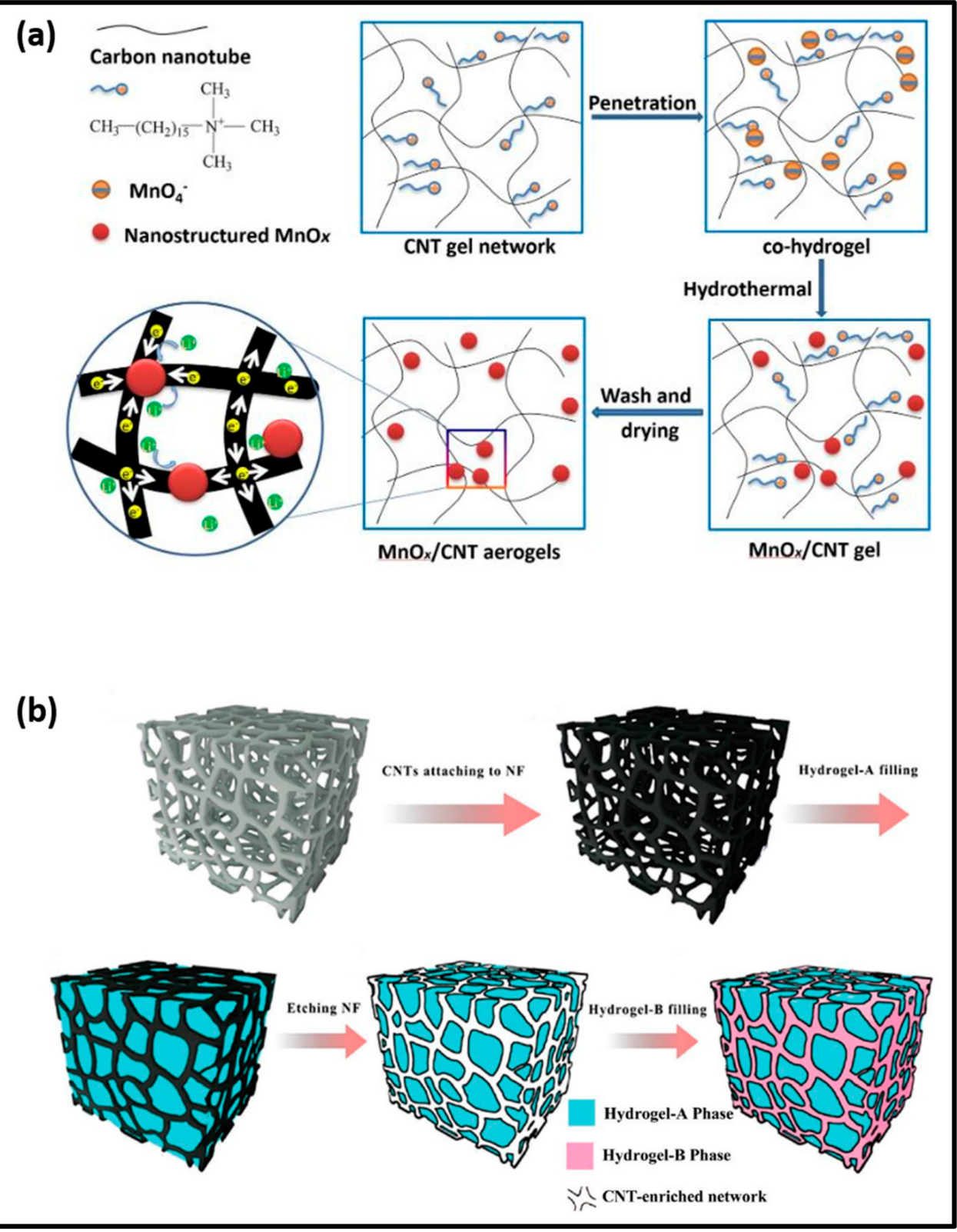

Figure 3. Scheme showing the synthesis of CNT-based hydrogels: (a) $\mathrm{MnO}_{\mathrm{x}} / \mathrm{CNT}$ aerogels [74], (b) general process of the double network hydrogel [75].

Polymer grafting is employed for the synthesis of CNTs grafted hydrogels. This technique provides the functionalization of the CNTs surface with a polymeric chain, which results in the shielding of the CNT surface [13,76]. This method offers a good dispersion of nanofillers along with their stronger interaction with polymers. Generally, protein and polypeptide-based CNT hydrogels have been synthesized through grafting techniques. Grafting-to and grafting-from polymerization for CNT polymers are two different grafting strategies involved in fabricating CNT hydrogels. In both approaches, the 
functional groups of the polymer chains are reacted with CNTs, leading to the formation of bioactive materials for biomedical applications. In addition, the intelligent device enable technique is an exciting technique that was applied to develop responsive hydrogel nanocomposites-based smart devices [77]. This method has been widely applied for the synthesis of hydrogel materials that are $\mathrm{pH}$ and ionic responsive. Significant research on the development of CNTs-based hydrogels has been done to obtain the desired functionality, shape, and size for specific applications.

\section{CNT-Based Antibacterial Applications}

It is well known that the wounded areas are more susceptible to bacterial infections. Depending upon the etiology and severity of the microbial invasion, the infections can cause minor to major damage to human life [78]. In the early stage of infection, the Grampositive bacteria such as Staphylococcus aureus and Streptococcus pyogenes are more populated, whereas the Gram-negative bacteria, such as Escherichia coli (E. coli) and Pseudomonas aeruginosa (P. aeruginosa), are populated later nearby wounded areas [79]. Usually, infection is avoided by activating the immune system for abolishing the invading pathogens. In this process, macrophages initiate the migration to the wound site and subsequently perform phagocytosis of the pathogens (destroyed in a phagolysosome or by nitric acid production). In a later stage of infection, the immune response is performed by activating T-helper lymphocytes, which secrete interferon- $\gamma$ and CD40 ligand to coordinate the immune adaptive and humoral response to kill and remove the invading bacteria [80]. In the passive stage of the immune system, infection occurs and causes the deterioration of granulation tissue, growth factors, and extracellular matrix components (collagen, elastin, and fibrin) and alters the normal wound-healing process $[81,82]$. Therefore, it is necessary to develop wound dressing materials to prevent bacterial penetration into the wound or reduce the microorganism's growth [83].

\subsection{Antibacterial Activity of Pristine CNT}

The antibacterial activity of CNTs has been studied widely against numerous bacteria, such as E. coli, Staphylococcus aureus, Staphylococcus emipermidis, and Bacillus subtilis. Microbes can rapidly increase their population in the wounded areas and adversely affect the wound-healing process [84]. Hence, antibacterial wound-healing patches are desirable and favorable for protecting the wound from infections and accelerating the healing process. Kang et al., demonstrated the antibacterial effect of SWCNTs against E. coli. SWCNTs showed strong antibacterial potential and damaged the bacterial cell membrane $[85,86]$. CNTs can directly damage the bacterial cell membrane or increase the reactive oxygen species (ROS) production, causing decrease cell viability [87]. Different conditions, such as $\mathrm{pH}$ temperature, retention time, and solute and solvent compositions, also affect bacterial eradication [88]. Dong et al., investigated the antibacterial properties of SWCNTs dispersed in different surfactant solutions, including sodium cholate, sodium dodecyl benzenesulfonate, and sodium dodecyl sulfate against Salmonella enterica (S. enterica), E. coli, and Enterococcus faecium. SWCNTs concentrations played a significant role in bacterial cell viability [89]. The probable mechanisms for CNTs induced are the inhibition of bacterial growth by impairing the respiratory chain; inhibition of energy metabolism; physical interaction with the cell membrane, formation of cell-CNTs aggregates, and induction of cell membrane disruption. SWCNTs have also shown excellent antimicrobial properties [90-92]. The size of CNTs contributes a considerable role in the deactivation of microorganisms. The smaller-sized CNTs have a larger surface-to-volume ratio, which helps to make strong bonds with the cell wall or membrane of bacteria, showing better antibacterial potential [93].

SWCNTs primarily aggregate with the cell wall, which is followed by induction of cell membrane rupture, hindering DNA replication [94]. It has also been mentioned that the surface charge of CNTs has a significant role in the inactivation of bacteria by cell membrane interruption [95]. SWCNTs have a specific surface area of approximately $407 \mathrm{~m}^{2} / \mathrm{g}$, which 
can remove $3.18 \times 10^{12} \mathrm{CFU} / \mathrm{mL}$ [96]. Bing et al., assessed the effect of CNTs' surface charge on bacterial death and found that positive and negative charge dots had antibacterial activity. Reactive oxygen species, such as hydroxyl radicals, are generated by the interaction of CNTs and the cell membrane, which kills the bacteria [97]. Yang et al., assessed that longer $(\approx 5 \mu \mathrm{m})$ SWCNTs make better aggregation and show more robust antimicrobial activity. The different activity was observed in the solid and liquid media. In solid media, shorted $(<1 \mu \mathrm{m})$ CNTs showed effective antimicrobial activity than the longer ones [98]. The MWCNTs with $50 \mu \mathrm{m}$ length wrap on all sides of a microbial cell and cause osmotic lysis. Whereas, in liquid media, longer CNT are more effective in bacterial cell damage. The aggregation or interaction between CNTs and the bacterial cell membrane is unavoidable because of their particular structure and strong van der Waals forces [99]. The tube diameter of CNT also affects the antimicrobial activity. Smaller diameters entail better interactions with the cell wall, mediating determinants to the cell [88]. CNTs with a $1.5 \mathrm{~nm}$ diameter act as needles connected to the membrane from one side, and in diameters of $15-30 \mathrm{~nm}$, CNTs are connected to the sidewalls [100]. Chen et al., demonstrated that CNTs have lower activity against Bacilli than Cocci [101]. The mechanism of these bacteriostatic properties is related to their diameter-dependent penetration and length-dependent wrapping on the disruption of cell walls and membranes of bacteria and intracellular substances such as DNA and RNA. In addition, they announced that bacterial survival duration after the direct connection with CNTs enhanced with the increasing length-to-diameter ratios with a linear coefficient $>0.79$ for all examined doses. Moreover, they reported that the shape, in addition to the size, of a particle can impact on the particle phagocytosis by macrophages.

The nanoscale size, shape, specific surface area, chemical composition, and surface structure of CNTs are the essential factors influencing its toxicity. It has been established that the larger the surface area, the higher the contact area with microbes, increasing the antimicrobial interaction and enhancing the killing mechanism. The dispersed CNTs exhibited significantly more toxic effects on bacterial cells than the aggregates. The inactivation of S. aureus, E. coli, and B. subtilis was increased from $30-50 \%$ to $90-100 \%$ by adding the functional groups to the surface to improve the dispersibility of the nanomaterials [102]. Additionally, the geometry of CNTs can also affect antimicrobial activity. It has been observed that SWCNTs are more practical to kill E. coli compared to MWCNTs. According to the authors, SWCNTs have better penetration capability into cell walls than MWCNTs due to their smaller diameter and high surface area, which helps for better interaction with cell surface [103]. SWCNTs with sharp diameters can easily penetrate the bacterial cell wall than MWCNTs [88]. Bacteria generate more stress-related gene products with small diameter CNTs [103]. Kang et al., performed a gene expression experiment that revealed the pathways involving membrane damaging, repairing, and lipid recycling, such as fatty acid beta-oxidation and glycolysis [103]. The fatty acid biosynthesis pathways were highly expressed in the presence of SWCNTs than MWCNTs exposure to bacteria. More lipids from the membrane were released to the media due to membrane damage/cell death in the presence of SWCNTs. In the fatty acid biosynthesis pathway, the upregulation of the synthesis of new lipid molecules occurred and was incorporated into the cells for cell growth or repair of the broken membrane. The high expression of glycolysis with SWCNTs indicates that the cells are required to produce more energy to survive the stress-related conditions. The by-products of Acetyl-CoA pathways are typically used to synthesize fatty acids to repair the membranes. Figure 4a represents a schematic summary of E. coli K21 gene expression stress response under exposure of CNT. 


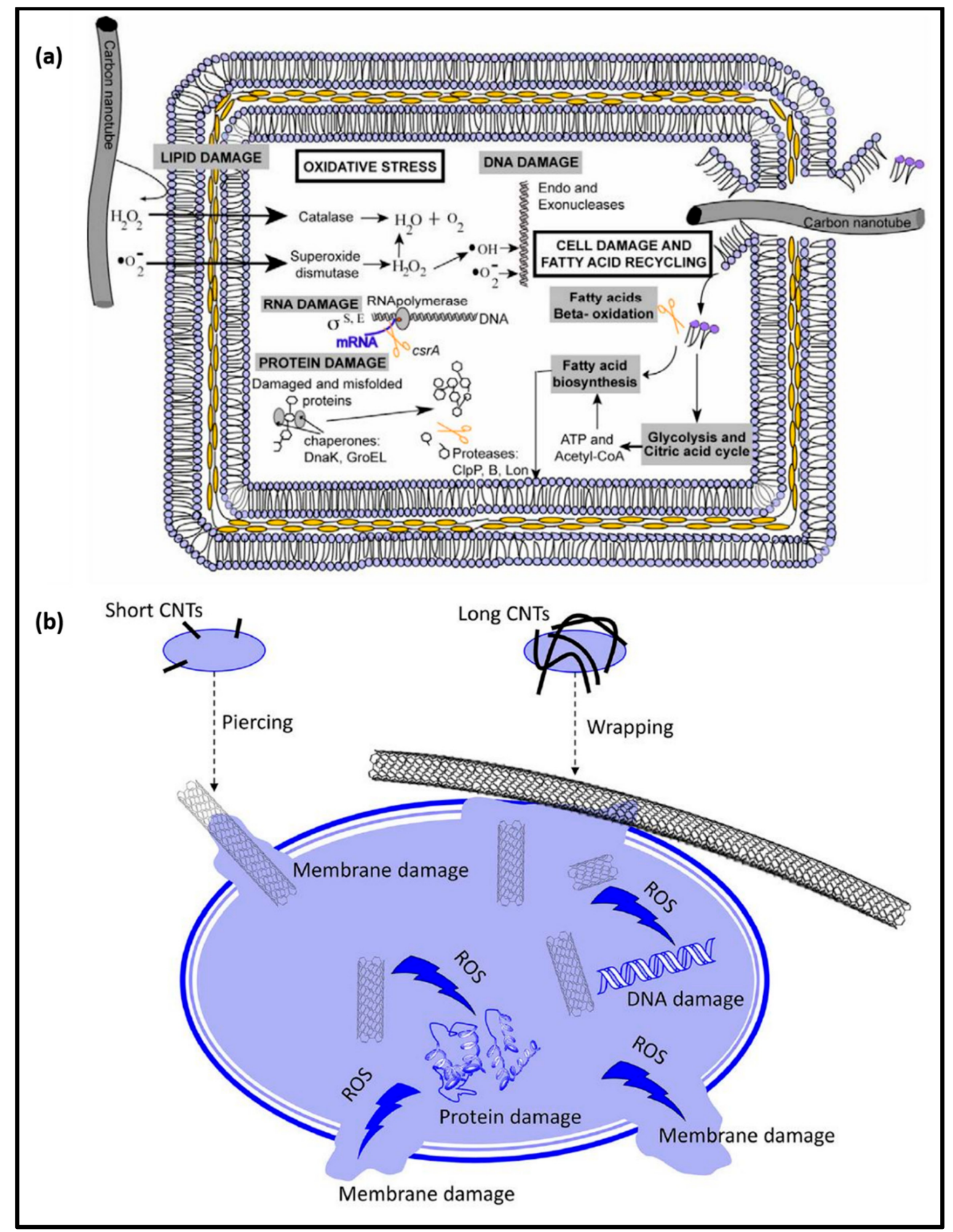

Figure 4. (a) Scheme showing antibacterial activity through cell membrane rupture in E. coli K12 bacteria [103], (b) Schematic diagram of bacteria killing through ROS mechanism in presence of long and short CNT [104].

The generation of $\mathrm{ROS}$ such as $\mathrm{O}^{-}{ }_{2}$ and $\mathrm{OH}^{-}$with $\mathrm{CNTs}$ is also responsible for killing the bacteria $[105,106]$. The reactive species oxidize the fatty acids in the cell membrane and damage the cell permeability, adversely affecting the cell functions $[105,107]$. A schematic mechanism of antibacterial activity by ROS generation is presented in Figure $4 \mathrm{~b}$. The greater expression of superoxide dismutase and catalase was observed in E. coli in 
the presence of CNTs. The DNA damage pathways and repair systems were activated with CNTs. A similar gene expression pattern has been previously observed in E. coli cells exposed to hydrogen peroxide and superoxide. Physical membrane damage and oxidative stress are the fundamental mechanisms for the toxicity of all carbon-based nanomaterials $[88,103,107,108]$. Cell contact time with CNT also influences antimicrobial activity [109]. Enhanced toxicity was observed in Gram-positive and Gram-negative bacteria in the presence of SWCNTs with increasing the contact time from 1 to $3 \mathrm{~h} \mathrm{[110].}$ Significant antimicrobial effects were observed in some Gram-positive bacteria after long exposure times (36h). The antimicrobial effects of CNTs also depend on bacterial cell wall characteristics. The Gram-positive bacteria have more resistance to CNTs because of the thicker peptidoglycan cell wall than Gram-negative bacteria [111]. However, more studies are needed better to understand the different tolerances of diverse bacteria to CNTs.

\subsection{Antibacterial Properties of CNT Composites}

CNTs combined with nanoparticles exhibited an improved antibacterial effect. Several studies have been reported to check the antibacterial effect of CNTs composites with chitosan and silver NP [112]. Dong et al., examined that CNTs conjugated with AgNPs exhibited superior antibacterial properties against E. coli [113]. This was attributed to the more significant disruption of the cell membrane in the presence of CNTs conjugated with AgNPs. Yuan et al., observed that the deposition of AgNPs on MWCNTs with poly(amidoamine) induced bacteriostatic effects against S. aureus, E. coli, and Pseudomonas aeruginosa [114].

Castle et al., prepared the MWCNTs/AgNPs composites and evaluated their biocompatibility and antibacterial potential [115]. Enhanced biocompatibility and antibacterial efficacy were observed in the developed composites. The antibacterial property of CNTs is explored to establish nanocomposite films. CNTs/poly(L-lysine) or poly(L-glutamic acid) composite films were synthesized and their antibacterial potential against $E$. coli and Staphylococcus epidermidis was evaluated. The composite films showed $90 \%$ of bacterial killing efficacy [116]. Gelatin/MWCNTs composite films demonstrated improved bacterial killing properties against Gram-negative and Gram-positive bacteria [117]. An improvement in physicochemical, mechanical, and electrical properties was observed in CNTs incorporated in gelatin. Lu et al., synthesized the poly(lactic acid) (PLA)/AgNPs/CNTs composites and examined their antibacterial potential against Staphylococcus haemolyticus [118]. The developed composite showed superior antibacterial properties against Staphylococcus haemolyticus. They observed that the combination of two nano-fillers demonstrated synergistic features to the polymeric matrix. The nanocomposite also exhibited remarkable thermo-mechanical and antibacterial properties. Benigno et al., developed the low-density poly(ethylene) (LDPE)/MWCNTs nanocomposites and monitored antimicrobial activity against $\mathrm{DH} 5 \alpha$ E. coli [119]. A significant enhancement in the antibacterial potential was observed in 1\% MWCNTs-added LDPE film. They also evaluated the effects of the developed nanocomposites on biofilms. They reported that the biofilms boosted the ability of E. coli to adhere to the surface of the materials, thereby attenuating the antimicrobial properties of MWCNTs. Aslan et al., prepared the composites with a combination of SWCNTs and poly(lactic-co-glycolic acid) (PLGA), which effectively declined the viability of both E. coli and S. epidermidis [111]. Table 3 summarizes the antimicrobial effect of CNT and its composite materials. 
Table 3. Application and aspect of CNT-based composites for antibacterial activity on various bacteria.

\begin{tabular}{|c|c|c|c|c|}
\hline CNT Composite & Treatment & Organism & Effect & Reference \\
\hline SLS-CNT/PES & Ultrafiltration & Escherichia coli (E. coli) & Antifouling and antibacterial & [120] \\
\hline $\mathrm{SCNT}_{-} \mathrm{SnO}_{2}$ & Wastewater treatment & $\begin{array}{l}\text { Escherichia coli and } \\
\text { Pseudomonas graminis }\end{array}$ & $\begin{array}{l}\text { Photolytic degradation and } \\
\text { Bactericidal activity }\end{array}$ & [121] \\
\hline PPy-co-PIn@CNT & $\begin{array}{l}\text { Anticorrosion coating to prevent } \\
\text { the surface of metals from being } \\
\text { damaged }\end{array}$ & $\begin{array}{l}\text { S. aureus and B. subtilis, E. coli, } \\
\text { and P. aeruginosa. }\end{array}$ & $\begin{array}{l}\text { Antibacterial and } \\
\text { anticorrosion activity }\end{array}$ & [122] \\
\hline (CNT/pra/Ag) & $\begin{array}{l}\text { Increased inhibitory activity } \\
\text { toward Gram-positive bacteria }\end{array}$ & $\begin{array}{l}\text { Staphylococcus aureus, } \\
\text { Pseudomonasaeruginosa, and E. } \\
\text { coli }\end{array}$ & Antibacterial activity & [123] \\
\hline $\mathrm{GO} / \mathrm{ZnO}-\mathrm{CNT}$ & $\begin{array}{l}\text { Treatment of } \\
\text { multidrug-resistant bacteria }\end{array}$ & E. coli $(\mathrm{DH} 5 \alpha)$ & $\begin{array}{l}\text { Damage the } E \text {. coli } \\
\text { cell membranes }\end{array}$ & [124] \\
\hline $\mathrm{CNT} / \mathrm{LaVO}_{4}$ & $\begin{array}{l}\text { Antibiotic } \\
\text { photodegradation }\end{array}$ & E. coli & $\begin{array}{l}\text { Low toxicity, improve } \\
\text { water quality }\end{array}$ & [125] \\
\hline $\mathrm{Cu} / \mathrm{CNT}$ & Enhance antimicrobial activity & S. aureus and E. coli & Antibacterial activity & [126] \\
\hline $\begin{array}{l}\mathrm{Co}_{0.7} \mathrm{Zn}_{0.3} \\
\mathrm{Fe}_{2} \mathrm{O}_{4} / \mathrm{PET} / \mathrm{Ag} / \mathrm{CNT}\end{array}$ & $\begin{array}{l}\text { Water-dispersible } \\
\text { antibacterial activity }\end{array}$ & $\begin{array}{l}\text { E. coli, } \\
\text { Pseudomonas aeruginosa, } \\
\text { Bacillus subtilis, Staphylococcus } \\
\text { aureus }\end{array}$ & Improved antibacterial activity & [127] \\
\hline $\mathrm{CNT} / \mathrm{MnO}_{2}$ & $\begin{array}{l}\text { Enhanced antibacterial activity } \\
\text { of Gram-negative bacteria }\end{array}$ & $\begin{array}{l}\text { Proteus mirabilis and } \\
\text { Escherichia coli }\end{array}$ & Inhibit bacterial growth. & [128] \\
\hline
\end{tabular}

SLS-sodium lignosulfonate, PES-poly(ethersulfone), $\mathrm{SCNT}_{-} \mathrm{SnO}_{2}$-sonicated $\mathrm{CNT}-\mathrm{SnO}_{2}$, PPy-co-Pin-pyrrole indole copolymer, prapramipexole, Ag-silver, $\mathrm{ZnO}$-zinc oxide, GO-graphene oxide, $\mathrm{LaVO}_{4}$-lanthanum vanadate, $\mathrm{Cu}$-copper, PET-poly(ethylene terephthalate), $\mathrm{MnO}_{2}$-manganese dioxide.

\section{CNT-Based Nanocomposites for Wound Healing}

CNTs enhance the biological activity of wound-healing materials due to their unique interaction pattern with biomolecules, cells, and nearby tissues [129,130]. As discussed above, wound healing is a natural physiological process that responds to any skin injury. This complicated mechanism involves sophisticated interactions between cell types, coagulation factors, connective tissue, cytokines, growth factors, and the vascular system $[2,131]$. The schematic wound-healing process is described in Figure $5 \mathrm{a}$, where four stages of wound healing are demonstrated. These stages are hemostasis, inflammatory, proliferative, and maturation phase.

The hemostasis phase is a narrowing of the blood vessels to stop bleeding immediately after an injury to the skin tissue [132]. The blood-clotting system is activated at this stage, and a barrier is formed to prevent excessive bleeding from the injury site. In this process, platelets are attached with collagen, which results in the activation of aggregates. Inflammation is the next stage in the wound-healing process, which is initiated by releasing inflammatory mediators (prostaglandins and histamine) to prepare the wound site for growing new tissue $[2,132,133]$. In this stage, neutrophils (white blood cells) are introduced into the wound to kill the bacteria and remove the inflammatory mediators. Usually, one to two days are required for complete localization of these cells in the injury, which results in continuous removal of residues. The movement of protein and other factors development by these cells results in immune cells' attention toward the wound for facilitating the repair of tissue. The next stage is the proliferative phase, where the wound site constructs a new connective tissue with extracellular matrix (ECM) and collagen $[133,134]$. This construction follows the contraction of wound edges, which significantly promotes wound healing.

Furthermore, the granulation process produces a new wound matrix, in which the ground substance provides a scaffold-like structure for the development of fresh blood capillaries and connective tissues. Re-epithelization is the last stage of proliferation, where the epithelial cells are transferred around the wound. This process is fast in the presence of a moist wound environment [135]. The maturation or remodeling phase is the final phase to the healing of the wound; it can last somewhere between 21 days and 2 years; the maturation period depends on the wound type and condition. In this phase, newly 
grown tissue becomes strong and flexible, and wound sites free from the blood capillaries, macrophages, and fibroblasts through apoptosis or undefined mechanisms $[131,133]$. However, this dynamic wound-healing process can be affected due to the local (infection, humidity, maceration) and systemic (age, nutritional status, body status) factors.

Generally, a wound starts with a minor injury, but it can extend without healing for longer durations, leading to a chronic wound condition. The typical chronic wounds are diabetic ulcers, venous and arterial ulcers, pressure ulcers, hypertrophic scars, fibrosis, and pressure sores. No doubt, normal wounds can turn into chronic severe injuries if some healing steps are impaired with specific features. In addition, a few factors such as diabetes, obesity, malnutrition, medication, and lifestyle habits (excessive smoking and excessive alcohol) can be a strong reason for impaired wound healing. Hence, this process is considered more dynamic than other biomedical treatment processes, which could appeal to the development of advanced devices/materials to accelerate this healing process more effectively [136].

He et al., fabricated non-antibiotic but CNT-based hydrogel for photothermal therapy of bacteria-infected skin wounds [137]. The composite was fabricated by N-carboxyethyl chitosan (CEC) benzaldehyde-terminated Pluronic F127/carbon nanotubes (PF127/CNT). The presence of CNT endowed the hydrogel with in vitro and in vivo photothermal antimicrobial activity and good conductivity. Figure $5 \mathrm{~b}$ shows the hemostatic capability of $\mathrm{CEC} / \mathrm{PF} / \mathrm{CNT} 2$ hydrogel in the mouse tail amputation model. In a recent study, $\mathrm{Xu}$ et al., developed a multifunctional conductive microporous nanocomposite hydrogel (MNHs) by air-in-water emulsion [138]. The emulsion was stabilized by colloidal hybrids of CNT and gelatin methacrylate (GelMA). The hydrogels demonstrated tunable pore size, electrical conductivity, and mechanical properties with varying concentrations of CNT. Decreased pore size and increased electrical conductivity were observed with $3 \mathrm{wt} \%$ of CNT compared to 0 and $1 \%$ CNT added samples. The hydrogel demonstrated remarkable antimicrobial and wound-healing performance on a murine dorsal skin model. The conductivity graph and in vivo wound treatment of $\mathrm{MNH} / \mathrm{CNT0}$ and $\mathrm{MNH} / \mathrm{CNT3}$ samples is shown in Figure 5c. The presence of CNT promoted the stability of emulsion and enhanced the conductivity and mechanical property of hydrogel. Zhao et al., developed injectable antibacterial and conductive nanocomposite cryogel with similar components (CNT and GelMA) with the addition of functionalized quaternerized chitosan [30]. Their results showed that $4 \mathrm{mg} / \mathrm{mL}$ CNT composition was outstanding for hemostatic application compared to gauze. The wound-healing performance was also compared with Tegaderm ${ }^{\mathrm{TM}}$ film, and the fabricated cryogels showed better results in the mouse-liver injury model. In another work, CNT was incorporated with chitosan and poly(acrylamide) to synthesize a multifunctional hydrogel. The film was prepared to deliver vascular endothelial growth factor (VEGF) and check the release pattern in the presence and absence of fluorescein isothiocyanate-tagged bovine serum albumin (FITC-BSA). The presence of CNT enhanced the interaction among cells and promoted cell proliferation. Figure $5 \mathrm{~d}$ represents the hematoxylin and eosin (H\&E) staining of regenerated granulation tissues from wound sites in different groups and their statistical analysis of tissue thickness [139].

He et al., developed a nitrogen-doped CNT encapsulating cobalt (N-CNTs@Co) nanoparticles for antibacterial wound-healing application [140]. The nanocomposite showed oxidase-mimicking activity, which could produce a large number of ROS in an acidic environment. The generation of ROS exhibited good antibacterial activity against Gram-positive Staphylococcus and Gram-negative Escherichia coli. To kill the bacteria, the ROS damaged the bacterial membrane and degraded its DNA. After the treatment of the N-CNTs@Co nanocomposite, the bacteria-infected wound shrank faster than the control group. The H\&E analysis confirmed the healing process by showing the high speed of hair follicle recovery, and finally, the skin surface was smooth. 


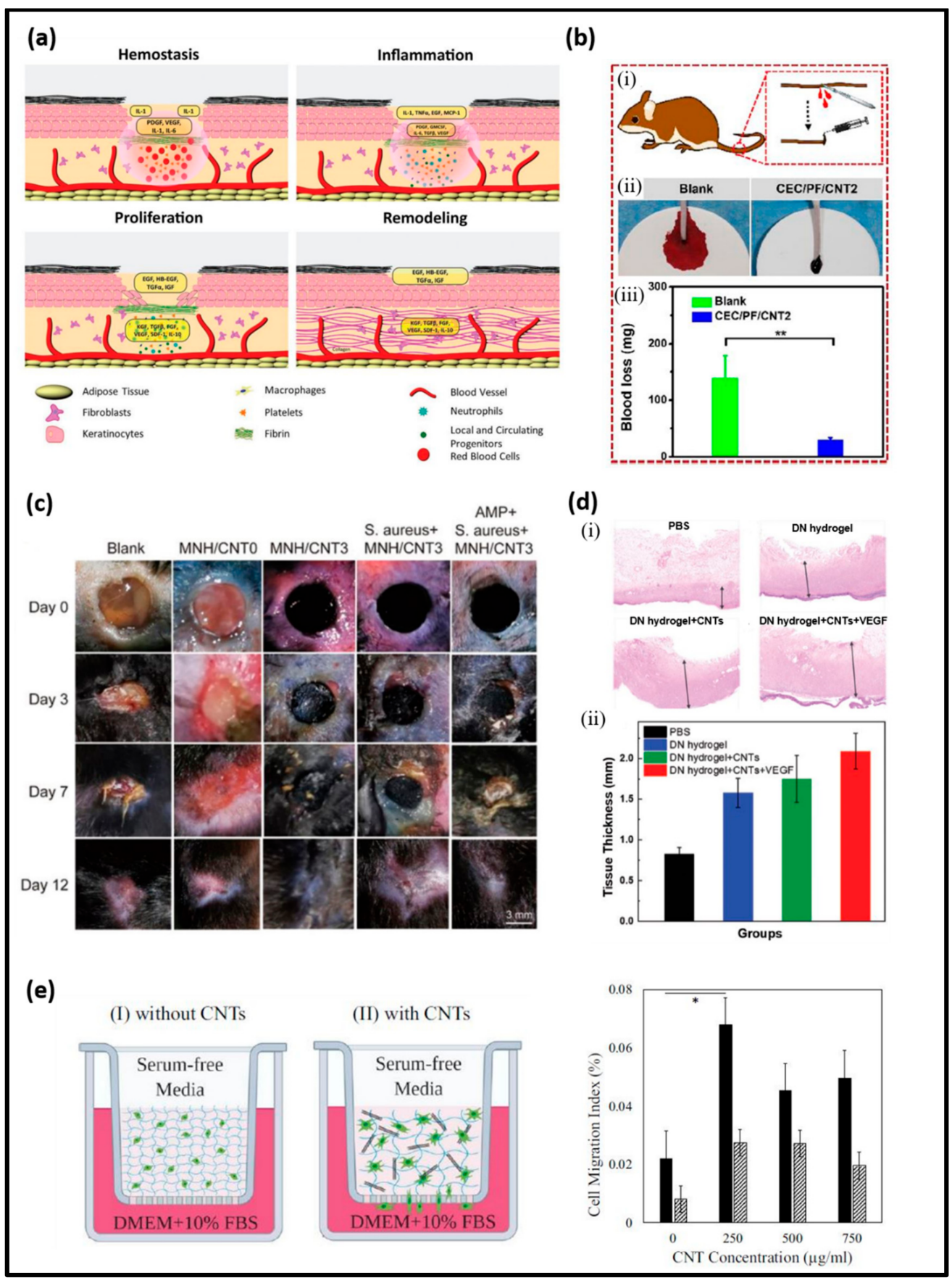

Figure 5. (a) Schematic representation of wound-healing phases in cutaneous wound-hemostasis, inflammation, proliferation, and remodeling [2], (b) (i) Scheme representation of mouse-tail amputation model, (ii) bloodstain photograph of mouse tail in blank and hydrogel group, (iii) quantitative data of blood loss $(n=5)$, ${ }^{* *} p<0.01$ [137], (c) In vivo wound-healing model evaluation of MNH hydrogels and observation of treatment in presence of S. aureus infection for 12 days [138], (d) (i) H\&E staining of different groups showing the progress in thickness of skin, (ii) respective statistical analysis of average connective tissue thickness in different groups [139], (e) Schematic of chemoattractantinduced cell migration assay using a modified Boyden Chamber experiment. The addition of CNT increased the porosity of the hydrogel and cell migration (left). The average cell migration index for the samples with varying concentration of CNT with (solid pattern) and without (diagonal pattern) chemoattractant. ${ }^{*} p<0.05$ corresponds to a significant difference (right) [35]. 
Similarly, Kittana et al., investigated and compared the effect of chitosan complexed SWCNT and MWCNT hydrogels for the wound-healing process [141]. Fibroblasts were viable in the presence of the complexes. The fabricated complexes showed effective organization and contraction of the extracellular matrix. The in vivo data demonstrated the re-epithelialization of the cells in wounded areas and an increase in fibrosis by both the complexes. The MWCNT-chitosan complex showed an enhanced effect in fibrosis formation and collagen deposition compared to the SWCNT-chitosan hybrid material. The inflammatory signs confirmed the wound-healing associated impact. Inflammation plays an essential role in the primary process of wound healing. Here, the activated neutrophils secrete more lysosomal enzymes that facilitate the cleavage and eliminate damaged structural proteins of the extracellular matrix [142]. In addition, the inflammatory process enhances the number of macrophages at the wound site, which secretes more inflammatory mediators and cleanses out the wound area.

Furthermore, it allows the migration of activated fibroblasts to the wound site [143]. Moreover, the activated fibroblasts gain greater capacity to contract the wound tissue and deposit more significant amounts of glycosaminoglycans and collagen, which are essential for tissue repair [144]. In the secondary stage, activated fibroblasts compensate for the damaged extracellular matrix by depositing large amounts of collagen (fibrosis), forming a scar. The next step includes healing, where the bulk of collagen in the scar is subjected to a long-lasting remodeling process over a year or more, which is facilitated by metalloproteinases secreted by fibroblasts and other cells to strengthen the repaired tissue. However, the fibrosis is never entirely resolved [145]. Hence, an increase in the inflammatory signs and collagen deposition can be indicated as an improvement in the wound-healing process, which is also associated with the improved re-epithelialization [141]. The application of CNT composites for cell proliferation and angiogenesis is included in Table 4.

Table 4. Application and aspect of CNT hybrids for cell proliferation and angiogenesis.

\begin{tabular}{|c|c|c|c|c|}
\hline CNT Composite & Treatment & Cell Line & Effect & Reference \\
\hline $\mathrm{rBC} / \mathrm{PPy} / \mathrm{CNT}$ & Wound healing & $\begin{array}{l}\text { The mouse embryo fibroblast } \\
\text { (NIH3T3) cell line }\end{array}$ & $\begin{array}{l}\text { Good biocompatibility, enhanced } \\
\text { cell proliferation, excellent } \\
\text { thermal stability, mechanical } \\
\text { properties, recoverability, and } \\
\text { good water-absorbing capability. }\end{array}$ & [146] \\
\hline PCL/CNT & $\begin{array}{l}\text { neuron differentiation } \\
\text { and regeneration }\end{array}$ & $\begin{array}{l}\text { human bone-derived } \\
\text { mesenchymal stem cells }\end{array}$ & $\begin{array}{l}\text { Improved cell adhesion and } \\
\text { differentiation. }\end{array}$ & [147] \\
\hline Ch-PCL/CNT & $\begin{array}{l}\text { Antibacterial activity and } \\
\text { other biomedical applications }\end{array}$ & L929 fibroblast cells & $\begin{array}{l}\text { Improved cell attachment and } \\
\text { proliferation, antibacterial activity } \\
\text { against Gram-positive and } \\
\text { Gram-negative bacteria. }\end{array}$ & [148] \\
\hline CNT: gel-CT & Cancer treatments & $\begin{array}{l}\text { WM266-4 human melanoma } \\
\text { cell line }\end{array}$ & $\begin{array}{l}\text { Induce cell growth inhibition and } \\
\text { cell death. }\end{array}$ & [149] \\
\hline$(\mathrm{OH})-\mathrm{CNTs}$ & $\begin{array}{l}\text { Stem cell-based } \\
\text { regenerative medicines. }\end{array}$ & $\begin{array}{l}\text { Canine bone marrow-derived } \\
\text { mesenchymal stem cells }\end{array}$ & $\begin{array}{l}\text { Positive influence on osteogenic } \\
\text { and chondrogenic differentiation } \\
\text { as well as neuronal differentiation. }\end{array}$ & [150] \\
\hline PVA-Ch-CNT & Cardiac differentiation & $\begin{array}{l}\text { Undifferentiated mesenchymal } \\
\text { stem cells (MSCs) }\end{array}$ & $\begin{array}{l}\text { Upregulation of cardiomyocytes } \\
\text { differentiation. Increased } \\
\text { conductivity, chemical stability, } \\
\text { and enhanced adherence. }\end{array}$ & [151] \\
\hline $\mathrm{HA} / \mathrm{CNT}$ & Dental application & & $\begin{array}{l}\text { Induce angiogenesis and exhibited } \\
\text { biocompatibility. Improved } \\
\text { mechanical properties }\end{array}$ & [152] \\
\hline MWCNT & $\begin{array}{l}\text { Influence breast cancer } \\
\text { metastatic cascades }\end{array}$ & BALB/c-derived 4T1 & $\begin{array}{l}\text { Enhances tumor angiogenesis and } \\
\text { metastatic processes. }\end{array}$ & [153] \\
\hline $\mathrm{CNT} / \mathrm{PU}$ & $\begin{array}{l}\text { Improved cytocompatibility } \\
\text { for cardiomyoblasts. }\end{array}$ & $\begin{array}{l}\mathrm{H} 9 \mathrm{c} 2 \text { cells and human umbilical } \\
\text { vein endothelial cells (HUVECs) }\end{array}$ & $\begin{array}{l}\text { Appropriate attachment, high } \\
\text { viability, and proliferation of } \\
\text { cardiomyoblasts. }\end{array}$ & [154] \\
\hline
\end{tabular}

rBC-regenerated bacterial cellulose, PPy-polypyrrole, PCL-poly(caprolactone), Ch-chitosan, gel-gelatin, CT-catechin, PVA-poly(vinyl alcohol), HA-hydroxyapatite, PU-polyurethane. 
Cell migration is usually determined based on the distance traveled by the cells or the number of migrated cells [155]. Ravanbakhsh et al., studied the cell migration of fibroblasts in the presence of carboxylated MWCNT [35]. To analyze the chemoattractantinduced cell migration of CNT-glycol chitosan hydrogels, a modified Boyden chamber was used. The results showed that even small $(250 \mu \mathrm{L} / \mathrm{mL})$ concentrations of CNT can remarkably increase the cell migration in hydrogels. However, high concentrations did not induce the cell migration further. The schematic representation of cell migration assay and their results for the average cell migration index is shown in Figure 5e. Gelatingrafted-dopamine (GT-DA) and poly(dopamine) coated CNT (CNT-PDA) hydrogels with chitosan were engineered to present multifunctional injectable hydrogel for antibacterial wound healing [156]. The hydrogel also demonstrated sustained delivery of doxycycline. Poly(dopamine)-coated CNT was incorporated due to its conductive, photothermal, and antibacterial properties. CNT is well known for its excellent electrical, mechanical, and thermal properties.

\section{Conclusions and Future Perspective}

The application of carbon nanotubes and metal nanoparticles could be considered a promising approach for disinfection purposes. In this review, we summarized the studies related to the design and current strategies for developing CNT hydrogel wound-healing applications. CNT hydrogel composites with conductive and antibacterial properties have been considered as a promising candidate in wound healing and antibacterial treatment due to their excellent electrical and mechanical properties. Advances in the research and development toward the development of multifunctional hydrogels composites using different strategies have been contributing to establish more effective devices for wound-healing applications and enable bringing out effective skin regenerations. However, few obstacles, including low drug resistance, low antibacterial properties, toxicity, and low physical strength, are associated with the hydrogel composites. Thus, CNT hydrogels with antibacterial agents and hydrogel matricesare adopted to solve these issues. However, the diversity of wound healing requires hydrogel composite materials with multifunction to resist infections in or around the wound, enabling an effective and fast healing process. In this contest, CNT hydrogel with multifunctionality ( $\mathrm{pH}$-responsive, self-healing hydrogel, conductive hydrogel) needs to be developed to meet the requirements of different wound environments and types to heal it efficiently. Hence, future research should explore more advanced strategies to design efficient hydrogel composite materials with null toxicity.CNTmultifunctional hydrogels will be more attractive wound-healing materials. These composites should possess certain advantages such as easy synthesis procedures, large-scale compatibility, economic viability, degradability, and ready availability. These sustainable aspects should be considered for the further development of CNT-based hydrogels.

In addition to CNT hydrogel's potential efficiency in wound healing and other biomedical applications, a few necessary research fields need to be addressed in the near future, such as (i) significant studies to understand the toxicity issues related to CNT hydrogel and developing the strategies to overcome these issues, (ii) the development of a multifunctional hydrogel hybrid composite as well as devices (patches in the form of nasal, ocular, oral, intrathecal) for an efficient recovery, (iii) research on the implementation and working mechanism of CNT hydrogel for the complete wound-healing process, (iv) sensing or detection of interacted hydrogel materials to confirm the progress of treatment, and (v) studies related to the hydrogel effect on inflammation and wound site recovery. More importantly, significant studies should be conducted on the applicability of CNT hydrogel materials to check their potential for other innovative biomedical applications such as tissue engineering, organ replacement, biosensing devices, DNA identifications, micro chemotaxis devices, cardiac construction, etc.

Author Contributions: Conceptualization, T.V.P., writing-original draft, T.V.P., S.D.D., K.G., A.R., writing-review and editing, D.K.P., Supervision, K.-T.L., funding acquisition, K.-T.L. All authors have read and agreed to the published version of the manuscript. 
Funding: This research was supported by the Basic Research Program through the National Research Foundation of Korea (NRF) funded by the Ministry of Education (NRF-2018R1A6A1A03025582), and the National Research Foundation of Korea (NRF-2019R1D1A3A03103828).

Institutional Review Board Statement: Not applicable.

Informed Consent Statement: Not applicable.

Data Availability Statement: Not applicable.

Acknowledgments: This study has been worked with the support of a research grant of Kangwon National University in 2021.

Conflicts of Interest: The authors declare no competing financial interests.

\section{References}

1. Khalil, H.; Cullen, M.; Chambers, H.; Carroll, M.; Walker, J. Reduction in wound healing times, cost of consumables and number of visits treated through the implementation of an electronic wound care system in rural Australia. Int. Wound J. 2016, 13, 945-950. [CrossRef] [PubMed]

2. Nethi, S.K.; Das, S.; Patra, C.R.; Mukherjee, S. Recent advances in inorganic nanomaterials for wound-healing applications. Biomater. Sci. 2019, 7, 2652-2674. [CrossRef] [PubMed]

3. Feily, A.; Moeineddin, F.; Mehraban, S. Physical Modalities in the Management of Wound (s). In Wound Healing-New Insights into Ancient Challenges; IntechOpen: London, UK, 2016.

4. Kosaric, N.; Kiwanuka, H.; Gurtner, G.C. Stem cell therapies for wound healing. Expert Opin. Biol. Ther. 2019, 19, 575-585. [CrossRef]

5. Gottrup, F.; Dissemond, J.; Baines, C.; Frykberg, R.; Jensen, P.Ø.; Kot, J.; Kröger, K.; Longobardi, P. Use of oxygen therapies in wound healing. J. Wound Care 2017, 26, S1-S43. [CrossRef] [PubMed]

6. Malone-Povolny, M.J.; Maloney, S.E.; Schoenfisch, M.H. Nitric oxide therapy for diabetic wound healing. Adv. Healthc. Mater. 2019, 8, 1801210. [CrossRef] [PubMed]

7. Parani, M.; Lokhande, G.; Singh, A.; Gaharwar, A.K. Engineered nanomaterials for infection control and healing acute and chronic wounds. ACS Appl. Mater. Interfaces 2016, 8, 10049-10069. [CrossRef] [PubMed]

8. Borena, B.M.; Martens, A.; Broeckx, S.Y.; Meyer, E.; Chiers, K.; Duchateau, L.; Spaas, J.H. Regenerative skin wound healing in mammals: State-of-the-art on growth factor and stem cell based treatments. Cell. Physiol. Biochem. 2015, 36, 1-23. [CrossRef] [PubMed]

9. Pereira, R.F.; Bártolo, P.J. Traditional therapies for skin wound healing. Adv. Wound Care 2014, 5, 208-229. [CrossRef]

10. Vieira, S.; Castelli, S.; Falconi, M.; Takarada, J.; Fiorillo, G.; Buzzetti, F.; Lombardi, P.; Desideri, A. Role of 13-(di)phenylalkyl berberine derivatives in the modulation of the activity of human topoisomerase IB. Int. J. Biol. Macromol. 2015, 77, 68-75. [CrossRef]

11. Hamdan, S.; Pastar, I.; Drakulich, S.; Dikici, E.; Tomic-Canic, M.; Deo, S.; Daunert, S. Nanotechnology-driven therapeutic interventions in wound healing: Potential uses and applications. ACS Cent. Sci. 2017, 3, 163-175. [CrossRef]

12. Korupalli, C.; Li, H.; Nguyen, N.; Mi, F.-L.; Chang, Y.; Lin, Y.-J.; Sung, H.-W. Conductive materials for healing wounds: Their incorporation in electroactive wound dressings, characterization, and perspectives. Adv. Healthc. Mater. 2021, 10, 2001384. [CrossRef]

13. Vashist, A.; Kaushik, A.; Vashist, A.; Sagar, V.; Ghosal, A.; Gupta, Y.K.; Ahmad, S.; Nair, M. Advances in carbon nanotubeshydrogel hybrids in nanomedicine for therapeutics. Adv. Healthc. Mater. 2018, 7, e1701213. [CrossRef]

14. Jeevanandam, J.; Barhoum, A.; Chan, Y.S.; Dufresne, A.; Danquah, M.K. Review on nanoparticles and nanostructured materials: History, sources, toxicity and regulations. Beilstein J. Nanotechnol. 2018, 9, 1050-1074. [CrossRef]

15. Xiang, C.; Zhang, Y.; Guo, W.; Liang, X.-J. Biomimetic carbon nanotubes for neurological disease therapeutics as inherent medication. Acta Pharm. Sin. B 2020, 10, 239-248. [CrossRef]

16. Saito, N.; Usui, Y.; Aoki, K.; Narita, N.; Shimizu, M.; Hara, K.; Ogiwara, N.; Nakamura, K.; Ishigaki, N.; Kato, H.; et al. Carbon nanotubes: Biomaterial applications. Chem. Soc. Rev. 2009, 38, 1897-1903. [CrossRef]

17. Alshehri, R.; Ilyas, A.M.; Hasan, A.; Arnaout, A.; Ahmed, F.; Memic, A. Carbon nanotubes in biomedical applications: Factors, mechanisms, and remedies of toxicity. J. Med. Chem. 2016, 59, 8149-8167. [CrossRef]

18. Liu, Y.; Zhou, J.; Zhang, X.; Liu, Z.; Wan, X.; Tian, J.; Wang, T.; Chen, Y. Synthesis, characterization and optical limiting property of covalently oligothiophene-functionalized graphene material. Carbon 2009, 47, 3113-3121. [CrossRef]

19. Sinha, N.; Yeow, J.T. Carbon nanotubes for biomedical applications. IEEE Trans. NanoBiosci. 2005, 4, 180-195. [CrossRef]

20. Prajapati, S.K.; Malaiya, A.; Kesharwani, P.; Soni, D.; Jain, A. Biomedical applications and toxicities of carbon nanotubes. Drug Chem. Toxicol. 2020, 1-16. [CrossRef]

21. Adorinni, S.; Rozhin, P.; Marchesan, S. Smart hydrogels meet carbon nanomaterials for new frontiers in medicine. Biomedicines 2021, 9, 570. [CrossRef]

22. Asadi, N.; Pazoki-Toroudi, H.; Del Bakhshayesh, A.R.; Akbarzadeh, A.; Davaran, S.; Annabi, N. Multifunctional hydrogels for wound healing: Special focus on biomacromolecular based hydrogels. Int. J. Biol. Macromol. 2021, 170, 728-750. [CrossRef] 
23. Kakaei, A.; Mirzaei, M. Cyclophosphamide@ CNT: In silico exploration of nano drug delivery system. Lab-in-Silico 2021, 2, 9-14.

24. Sohrabi, N.; Alihosseini, A.; Pirouzfar, V.; Pedram, M.Z. Analysis of dynamics targeting CNT-based drug delivery through lung cancer cells: Design, simulation, and computational approach. Membranes 2020, 10, 283. [CrossRef]

25. Manoj Kumar, R.; Rajesh, K.; Haldar, S.; Gupta, P.; Murali, K.; Roy, P.; Lahiri, D. Surface modification of CNT reinforced UHMWPE composite for sustained drug delivery. J. Drug Deliv. Sci. Technol. 2019, 52, 748-759. [CrossRef]

26. Nikfar, Z.; Shariatinia, Z. DFT computational study on the phosphate functionalized SWCNTs as efficient drug delivery systems for anti-osteoporosis zolendronate and risedronate drugs. Phys. E Low-Dimens. Syst. Nanostruct. 2017, 91, 41-59. [CrossRef]

27. Nazeri, N.; Karimi, R.; Ghanbari, H. The effect of surface modification of poly-lactide-co-glycolide/carbon nanotube nanofibrous scaffolds by laminin protein on nerve tissue engineering. J. Biomed. Mater. Res. Part. A 2021, 109, 159-169. [CrossRef]

28. Wan, Q.; Xu, Y.; Chen, X.; Xiao, H. Exhaled gas detection by a novel Rh-doped CNT biosensor for prediagnosis of lung cancer: A DFT study. Mol. Phys. 2018, 116, 2205-2212. [CrossRef]

29. Zhang, X.; Qin, M.; Xu, M.; Miao, F.; Merzougui, C.; Zhang, X.; Wei, Y.; Chen, W.; Huang, D. The fabrication of antibacterial hydrogels for wound healing. Eur. Polym. J. 2021, 146, 110268. [CrossRef]

30. Zhao, X.; Guo, B.; Wu, H.; Liang, Y.; Ma, P.X. Injectable antibacterial conductive nanocomposite cryogels with rapid shape recovery for noncompressible hemorrhage and wound healing. Nat. Commun. 2018, 9, 2784. [CrossRef]

31. Sousa, M.P.; Neto, A.I.; Correia, T.R.; Miguel, S.P.; Matsusaki, M.; Correia, I.J.; Mano, J.F. Bioinspired multilayer membranes as potential adhesive patches for skin wound healing. Biomater. Sci. 2018, 6, 1962-1975. [CrossRef]

32. Zhao, X.; Sun, X.; Yildirimer, L.; Lang, Q.; Lin, Z.Y.; Zheng, R.; Zhang, Y.; Cui, W.; Annabi, N.; Khademhosseini, A. Cell infiltrative hydrogel fibrous scaffolds for accelerated wound healing. Acta Biomater. 2017, 49, 66-77. [CrossRef] [PubMed]

33. Tavakoli, J.; Mirzaei, S.; Tang, Y. Cost-effective double-layer hydrogel composites for wound dressing applications. Polymers 2018, 10, 305. [CrossRef] [PubMed]

34. Sun, H.; Mou, Y.; Li, Y.; Li, X.; Chen, Z.; Duval, K.; Huang, Z.; Dai, R.; Tang, L.; Tian, F. Carbon nanotube-based substrates promote cardiogenesis in brown adipose-derived stem cells via $\beta 1$-integrin-dependent TGF- $\beta 1$ signaling pathway. Int. J. Nanomed. 2016, $11,4381$.

35. Ravanbakhsh, H.; Bao, G.; Mongeau, L. Carbon nanotubes promote cell migration in hydrogels. Sci. Rep. 2020, 10, 2543. [CrossRef]

36. Shi, H.; Liu, H.; Luan, S.; Shi, D.; Yan, S.; Liu, C.; Li, R.K.Y.; Yin, J. Effect of polyethylene glycol on the antibacterial properties of polyurethane/carbon nanotube electrospun nanofibers. RSC Adv. 2016, 6, 19238-19244. [CrossRef]

37. Nosrati, H.; Aramideh Khouy, R.; Nosrati, A.; Khodaei, M.; Banitalebi-Dehkordi, M.; Ashrafi-Dehkordi, K.; Sanami, S.; Alizadeh, Z. Nanocomposite scaffolds for accelerating chronic wound healing by enhancing angiogenesis. J. Nanobiotechnol. 2021, 19, 1. [CrossRef]

38. Iijima, S. Helical microtubules of graphitic carbon. Nature 1991, 354, 56-58. [CrossRef]

39. Ahmad, M.; Silva, S.R.P. Low temperature growth of carbon nanotubes-A review. Carbon 2020, 158, 24-44. [CrossRef]

40. Gupta, N.; Gupta, S.M.; Sharma, S.K. Carbon nanotubes: Synthesis, properties and engineering applications. Carbon Lett. 2019, 29, 419-447. [CrossRef]

41. Faraji, S.; Stano, K.L.; Yildiz, O.; Li, A.; Zhu, Y.; Bradford, P.D. Ultralight anisotropic foams from layered aligned carbon nanotube sheets. Nanoscale 2015, 7, 17038-17047. [CrossRef]

42. Lee, E.; Salgado, R.A.; Lee, B.; Sumant, A.V.; Rajh, T.; Johnson, C.; Balandin, A.A.; Shevchenko, E.V. Design of lithium cobalt oxide electrodes with high thermal conductivity and electrochemical performance using carbon nanotubes and diamond particles. Carbon 2018, 129, 702-710. [CrossRef]

43. Marconnet, A.M.; Panzer, M.A.; Goodson, K.E. Thermal conduction phenomena in carbon nanotubes and related nanostructured materials. Rev. Mod. Phys. 2013, 85, 1295-1326. [CrossRef]

44. Han, Z.; Fina, A. Thermal conductivity of carbon nanotubes and their polymer nanocomposites: A review. Prog. Polym. Sci. 2011, 36, 914-944. [CrossRef]

45. Maruyama, S. A molecular dynamics simulation of heat conduction of a finite length single-walled carbon nanotube. Microscale Thermophys. Eng. 2003, 7, 41-50. [CrossRef]

46. Kumanek, B.; Janas, D. Thermal conductivity of carbon nanotube networks: A review. J. Mater. Sci. 2019, 54, 7397-7427. [CrossRef]

47. Berber, S.; Kwon, Y.-K.; Tománek, D. Unusually high thermal conductivity of carbon nanotubes. Phys. Rev. Lett. 2000, 84, 4613-4616. [CrossRef]

48. Osman, M.A.; Srivastava, D. Temperature dependence of the thermal conductivity of single-wall carbon nanotubes. Nanotechnology 2001, 12, 21. [CrossRef]

49. Cao, Q.; Yu, Q.; Connell, D.W.; Yu, G. Titania/carbon nanotube composite (TiO2/CNT) and its application for removal of organic pollutants. Clean Technol. Environ. Policy 2013, 15, 871-880. [CrossRef]

50. Simon, J.; Flahaut, E.; Golzio, M. Overview of carbon nanotubes for biomedical applications. Materials 2019, 12, 624. [CrossRef]

51. Rathinavel, S.; Priyadharshini, K.; Panda, D. A review on carbon nanotube: An overview of synthesis, properties, functionalization, characterization, and the application. Mater. Sci. Eng. B 2021, 268, 115095. [CrossRef]

52. Vander Wal, R.L.; Berger, G.M.; Ticich, T.M. Carbon nanotube synthesis in a flame using laser ablation for in situ catalyst generation. Appl. Phys. A 2003, 77, 885-889. [CrossRef]

53. Shah, K.A.; Tali, B.A. Synthesis of carbon nanotubes by catalytic chemical vapour deposition: A review on carbon sources, catalysts and substrates. Mater. Sci. Semicond. Process. 2016, 41, 67-82. [CrossRef] 
54. Arora, N.; Sharma, N.N. Arc discharge synthesis of carbon nanotubes: Comprehensive review. Diam. Relat. Mater. 2014, 50, 135-150. [CrossRef]

55. Anzar, N.; Hasan, R.; Tyagi, M.; Yadav, N.; Narang, J. Carbon nanotube-A review on synthesis, properties and plethora of applications in the field of biomedical science. Sens. Int. 2020, 1, 100003. [CrossRef]

56. Qu, J.; Zhao, X.; Liang, Y.; Zhang, T.; Ma, P.X.; Guo, B. Antibacterial adhesive injectable hydrogels with rapid self-healing, extensibility and compressibility as wound dressing for joints skin wound healing. Biomaterials 2018, 183, 185-199. [CrossRef]

57. Zhang, M.; Chen, S.; Zhong, L.; Wang, B.; Wang, H.; Hong, F. Zn ${ }^{2+}$-loaded TOBC nanofiber-reinforced biomimetic calcium alginate hydrogel for antibacterial wound dressing. Int. J. Biol. Macromol. 2020, 143, 235-242. [CrossRef]

58. Liang, Y.; Zhao, X.; Hu, T.; Chen, B.; Yin, Z.; Ma, P.X.; Guo, B. Adhesive hemostatic conducting injectable composite hydrogels with sustained drug release and photothermal antibacterial activity to promote full-thickness skin regeneration during wound healing. Small 2019, 15, 1900046. [CrossRef] [PubMed]

59. Ghobril, C.; Grinstaff, M.W. The chemistry and engineering of polymeric hydrogel adhesives for wound closure: A tutorial. Chem. Soc. Rev. 2015, 44, 1820-1835. [CrossRef] [PubMed]

60. Gaharwar, A.K.; Peppas, N.A.; Khademhosseini, A. Nanocomposite hydrogels for biomedical applications. Biotechnol. Bioeng. 2014, 111, 441-453. [CrossRef] [PubMed]

61. Guan, Q.; Lin, G.; Gong, Y.; Wang, J.; Tan, W.; Bao, D.; Liu, Y.; You, Z.; Sun, X.; Wen, Z.; et al. Highly efficient self-healable and dual responsive hydrogel-based deformable triboelectric nanogenerators for wearable electronics. J. Mater. Chem. A 2019, 7, 13948-13955. [CrossRef]

62. Lei, Z.; Wu, P. A highly transparent and ultra-stretchable conductor with stable conductivity during large deformation. Nat. Commun. 2019, 10, 3429. [CrossRef]

63. Jin, X.; Shang, Y.; Zou, Y.; Xiao, M.; Huang, H.; Zhu, S.; Liu, N.; Li, J.; Wang, W.; Zhu, P. Injectable hypoxia-induced conductive hydrogel to promote diabetic wound healing. ACS Appl. Mater. Interfaces 2020, 12, 56681-56691. [CrossRef]

64. Chen, Y.; Wu, W.; Yu, J.; Wang, Y.; Zhu, J.; Hu, Z. Mechanical strong stretchable conductive multi-stimuli-responsive nanocomposite double network hydrogel as biosensor and actuator. J. Biomater. Sci. Polym. Ed. 2020, 31, 1770-1792. [CrossRef]

65. Chen, Z.; Chen, Y.; Hedenqvist, M.S.; Chen, C.; Cai, C.; Li, H.; Liu, H.; Fu, J. Multifunctional conductive hydrogels and their applications as smart wearable devices. J. Mater. Chem. B 2021, 9, 2561-2583. [CrossRef]

66. Muthuswamy, S.; Viswanathan, A.; Yegappan, R.; Selvaprithiviraj, V.; Vasudevan, A.K.; Biswas, R.; Jayakumar, R. Antistaphylococcal and neutrophil chemotactic injectable k-carrageenan hydrogel for infectious wound healing. ACS Appl. Bio Mater. 2019, 2, 378-387. [CrossRef]

67. Han, W.; Zhou, B.; Yang, K.; Xiong, X.; Luan, S.; Wang, Y.; Xu, Z.; Lei, P.; Luo, Z.; Gao, J.; et al. Biofilm-inspired adhesive and antibacterial hydrogel with tough tissue integration performance for sealing hemostasis and wound healing. Bioact. Mater. 2020, 5, 768-778. [CrossRef]

68. Annabi, N.; Rana, D.; Shirzaei Sani, E.; Portillo-Lara, R.; Gifford, J.L.; Fares, M.M.; Mithieux, S.M.; Weiss, A.S. Engineering a sprayable and elastic hydrogel adhesive with antimicrobial properties for wound healing. Biomaterials 2017, 139, 229-243. [CrossRef]

69. Tantiwatcharothai, S.; Prachayawarakorn, J. Property improvement of antibacterial wound dressing from basil seed (O. basilicum L.) mucilage- ZnO nanocomposite by borax cross-linking. Carbohydr. Polym. 2020, 227, 115360. [CrossRef]

70. Meng, L.; Fu, C.; Lu, Q. Advanced technology for functionalization of carbon nanotubes. Prog. Nat. Sci. 2009, 19, 801-810. [CrossRef]

71. Wu, Y.; Xia, M.; Fan, Q.; Zhu, M. Designable synthesis of nanocomposite hydrogels with excellent mechanical properties based on chemical cross-linked interactions. Chem. Commun. 2010, 46, 7790-7792. [CrossRef]

72. Yang, B.X.; Pramoda, K.P.; Xu, G.Q.; Goh, S.H. Mechanical reinforcement of polyethylene using polyethylene-grafted multiwalled carbon nanotubes. Adv. Funct. Mater. 2007, 17, 2062-2069. [CrossRef]

73. De France, K.J.; Chan, K.J.W.; Cranston, E.D.; Hoare, T. Enhanced mechanical properties in cellulose nanocrystalpoly(oligoethylene glycol methacrylate) injectable nanocomposite hydrogels through control of physical and chemical cross-linking. Biomacromolecules 2016, 17, 649-660. [CrossRef] [PubMed]

74. Liu, Y.; Liu, M.; Zheng, P.; Ge, D.; Yang, L. Controllable hydrogel-thermal synthesis of Mn2O3/CNT aerogels: Shape evolution, growth mechanism and electrochemical properties. Mater. Des. 2019, 182, 108022. [CrossRef]

75. Ying, Z.; Wang, Q.; Xie, J.; Li, B.; Lin, X.; Hui, S. Novel electrically-conductive electro-responsive hydrogels for smart actuators with a carbon-nanotube-enriched three-dimensional conductive network and a physical-phase-type three-dimensional interpenetrating network. J. Mater. Chem. C 2020, 8, 4192-4205. [CrossRef]

76. Roy, S.; Das, T.; Ming, Y.; Chen, X.; Yue, C.Y.; Hu, X. Specific functionalization and polymer grafting on multi-walled carbon nanotubes to fabricate advanced nylon 12 composites. J. Mater. Chem. A 2014, 2, 3961-3970. [CrossRef]

77. Liu, S.; Gao, G.; Xiao, Y.; Fu, J. Tough and responsive oppositely charged nanocomposite hydrogels for use as bilayer actuators assembled through interfacial electrostatic attraction. J. Mater. Chem. B 2016, 4, 3239-3246. [CrossRef]

78. Ki, V.; Rotstein, C. Bacterial skin and soft tissue infections in adults: A review of their epidemiology, pathogenesis, diagnosis, treatment and site of care. Can. J. Infect. Dis. Med. Microbiol. 2008, 19, 173-184. [CrossRef]

79. Cardona, A.F.; Wilson, S.E. Skin and soft-tissue infections: A critical review and the role of telavancin in their treatment. Clin. Infect. Dis. Off. Publ. Infect. Dis. Soc. Am. 2015, 61 (Suppl. 2), S69-S78. [CrossRef] 
80. Andonova, M.; Urumova, V. Immune surveillance mechanisms of the skin against the stealth infection strategy of Pseudomonas aeruginosa-Review. Comp. Immunol. Microbiol. Infect. Dis. 2013, 36, 433-448. [CrossRef]

81. Han, G.; Zhang, W. Improved biclique cryptanalysis of the lightweight block cipher piccolo. Secur. Commun. Netw. 2017, 2017, 7589306. [CrossRef]

82. Siddiqui, A.R.; Bernstein, J.M. Chronic wound infection: Facts and controversies. Clin. Dermatol. 2010, 28, 519-526. [CrossRef]

83. Vig, K.; Chaudhari, A.; Tripathi, S.; Dixit, S.; Sahu, R.; Pillai, S.; Dennis, V.A.; Singh, S.R. Advances in skin regeneration using tissue engineering. Int. J. Mol. Sci. 2017, 18, 789. [CrossRef]

84. Unalan, I.; Endlein, S.J.; Slavik, B.; Buettner, A.; Goldmann, W.H.; Detsch, R.; Boccaccini, A.R. Evaluation of electrospun poly( $\varepsilon-$ caprolactone)/gelatin nanofiber mats containing clove essential oil for antibacterial wound dressing. Pharmaceutics 2019, 11, 570. [CrossRef]

85. Kang, S.; Pinault, M.; Pfefferle, L.D.; Elimelech, M. Single-walled carbon nanotubes exhibit strong antimicrobial activity. Langmuir ACS J. Surf. Colloids 2007, 23, 8670-8673. [CrossRef]

86. Maleki Dizaj, S.; Mennati, A.; Jafari, S.; Khezri, K.; Adibkia, K. Antimicrobial activity of carbon-based nanoparticles. Adv. Pharm. Bull. 2015, 5, 19-23. [CrossRef]

87. Mallaiah, D. Antibacterial activity by functionalized carbon nanotubes. In Nanostructures for Antimicrobial and Antibiofilm Applications; Prasad, R., Siddhardha, B., Dyavaiah, M., Eds.; Springer International Publishing: Cham, Switzeralnd, 2020; pp. 63-77.

88. Smith, S.C.; Rodrigues, D.F. Carbon-based nanomaterials for removal of chemical and biological contaminants from water: A review of mechanisms and applications. Carbon 2015, 91, 122-143. [CrossRef]

89. Dong, L.; Henderson, A.; Field, C. Antimicrobial activity of single-walled carbon nanotubes suspended in different surfactants. J. Nanotechnol. 2012, 2012, 928924. [CrossRef]

90. Assali, M.; Zaid, A.N.; Abdallah, F.; Almasri, M.; Khayyat, R. Single-walled carbon nanotubes-ciprofloxacin nanoantibiotic: Strategy to improve ciprofloxacin antibacterial activity. Int. J. Nanomed. 2017, 12, 6647-6659. [CrossRef]

91. Sapkota, K.P.; Hassan, M.M.; Shrestha, S.; Hanif, M.A.; Islam, M.A.; Akter, J.; Abbas, H.G.; Hahn, J.R. Heterojunction formation between copper(II) oxide nanoparticles and single-walled carbon nanotubes to enhance antibacterial performance. Int. J. Pharm. 2020, 590, 119937. [CrossRef]

92. Masoumeh, A.M.; Nejad, H.R.; Pardis, S.; Ali, K.N.R. Improving antibacterial activity of methicillin by conjugation to functionalized single-wall carbon nanotubes against S. aureus. Res. Sq. 2021. [CrossRef]

93. Khan, A.A.P.; Khan, A.; Rahman, M.M.; Asiri, A.M.; Oves, M. Lead sensors development and antimicrobial activities based on graphene oxide/carbon nanotube/poly(O-toluidine) nanocomposite. Int. J. Biol. Macromol. 2016, 89, 198-205. [CrossRef]

94. Ding, L.; Wang, H.; Liu, D.; Zeng, X.-A.; Mao, Y. Bacteria capture and inactivation with functionalized multi-walled carbon nanotubes (MWCNTs). J. Nanosci. Nanotechnol. 2020, 20, 2055-2062. [CrossRef]

95. Li, P.; Poon, Y.F.; Li, W.; Zhu, H.-Y.; Yeap, S.H.; Cao, Y.; Qi, X.; Zhou, C.; Lamrani, M.; Beuerman, R.W.; et al. A polycationic antimicrobial and biocompatible hydrogel with microbe membrane suctioning ability. Nat. Mater. 2011, 10, 149-156. [CrossRef]

96. Brady-Estévez, A.S.; Kang, S.; Elimelech, M. A single-walled-carbon-nanotube filter for removal of viral and bacterial pathogens. Small 2008, 4, 481-484. [CrossRef]

97. Dwyer, D.J.; Camacho, D.M.; Kohanski, M.A.; Callura, J.M.; Collins, J.J. Antibiotic-induced bacterial cell death exhibits physiological and biochemical hallmarks of apoptosis. Mol. Cell 2012, 46, 561-572. [CrossRef]

98. Yang, C.; Mamouni, J.; Tang, Y.; Yang, L. Antimicrobial activity of single-walled carbon nanotubes: Length effect. Langmuir ACS J. Surf. Colloids 2010, 26, 16013-16019. [CrossRef]

99. Johnston, H.J.; Hutchison, G.R.; Christensen, F.M.; Peters, S.; Hankin, S.; Aschberger, K.; Stone, V. A critical review of the biological mechanisms underlying the in vivo and in vitro toxicity of carbon nanotubes: The contribution of physico-chemical characteristics. Nanotoxicology 2010, 4, 207-246. [CrossRef]

100. Kim, K.-I.; Kim, D.-A.; Patel, K.D.; Shin, U.S.; Kim, H.-W.; Lee, J.-H.; Lee, H.-H. Carbon nanotube incorporation in PMMA to prevent microbial adhesion. Sci. Rep. 2019, 9, 4921. [CrossRef] [PubMed]

101. Chen, H.; Wang, B.; Gao, D.; Guan, M.; Zheng, L.; Ouyang, H.; Chai, Z.; Zhao, Y.; Feng, W. Broad-spectrum antibacterial activity of carbon nanotubes to human gut bacteria. Small 2013, 9, 2735-2746. [CrossRef] [PubMed]

102. Murugan, E.; Vimala, G. Effective functionalization of multi-walled carbon nanotube with amphiphilic poly(propyleneimine) dendrimer carrying silver nanoparticles for better dispersability and antimicrobial activity. J. Colloid Interface Sci. 2011, 357, 354-365. [CrossRef] [PubMed]

103. Kang, S.; Herzberg, M.; Rodrigues, D.F.; Elimelech, M. Antibacterial effects of carbon nanotubes: Size does matter! Langmuir ACS J. Surf. Colloids 2008, 24, 6409-6413. [CrossRef]

104. Song, B.; Xu, P.; Zeng, G.; Gong, J.; Zhang, P.; Feng, H.; Liu, Y.; Ren, X. Carbon nanotube-based environmental technologies: The adopted properties, primary mechanisms, and challenges. Rev. Environ. Sci. Bio/Technol. 2018, 17, 571-590. [CrossRef]

105. Kang, S.; Mauter, M.S.; Elimelech, M. Physicochemical determinants of multiwalled carbon nanotube bacterial cytotoxicity. Environ. Sci. Technol. 2008, 42, 7528-7534. [CrossRef]

106. Akhavan, O.; Ghaderi, E. Toxicity of graphene and graphene oxide nanowalls against bacteria. ACS Nano 2010, 4, 5731-5736. [CrossRef] 
107. Boczkowski, J.; Lanone, S. Respiratory toxicities of nanomaterials-A focus on carbon nanotubes. Adv. Drug Deliv. Rev. 2012, 64, 1694-1699. [CrossRef]

108. Vecitis, C.D.; Zodrow, K.R.; Kang, S.; Elimelech, M. Electronic-structure-dependent bacterial cytotoxicity of single-walled carbon nanotubes. ACS Nano 2010, 4, 5471-5479. [CrossRef]

109. Du, J.; Wang, S.; You, H.; Zhao, X. Understanding the toxicity of carbon nanotubes in the environment is crucial to the control of nanomaterials in producing and processing and the assessment of health risk for human: A review. Environ. Toxicol. Pharmacol. 2013, 36, 451-462. [CrossRef]

110. Kang, S.; Mauter, M.S.; Elimelech, M. Microbial cytotoxicity of carbon-based nanomaterials: Implications for river water and wastewater effluent. Environ. Sci. Technol. 2009, 43, 2648-2653. [CrossRef]

111. Aslan, S.; Loebick, C.Z.; Kang, S.; Elimelech, M.; Pfefferle, L.D.; Van Tassel, P.R. Antimicrobial biomaterials based on carbon nanotubes dispersed in poly(lactic-co-glycolic acid). Nanoscale 2010, 2, 1789-1794. [CrossRef]

112. Azizi-Lalabadi, M.; Hashemi, H.; Feng, J.; Jafari, S.M. Carbon nanomaterials against pathogens; the antimicrobial activity of carbon nanotubes, graphene/graphene oxide, fullerenes, and their nanocomposites. Adv. Colloid Interface Sci. 2020, 284, 102250. [CrossRef]

113. Dong, X.; Koo, Y.; Tang, Y.; Yun, Y.; Yang, L. Superior antibacterial activity of photochemical synthesized Ag-CNT composites and their synergistic effects in combination with other antimicrobial agents. Nanomed. Nanotechnol. 2015, 6, 279.

114. Yuan, W.; Jiang, G.; Che, J.; Qi, X.; Xu, R.; Chang, M.W.; Chen, Y.; Lim, S.Y.; Dai, J.; Chan-Park, M.B. Deposition of silver nanoparticles on multi-walled carbon nanotubes grafted with hyperbranched poly(amidoamine) and their antimicrobial effects. $J$. Phys. Chem. C 2008, 112, 18754-18759. [CrossRef]

115. Castle, A.B.; Gracia-Espino, E.; Nieto-Delgado, C.; Terrones, H.; Terrones, M.; Hussain, S. Hydroxyl-functionalized and $\mathrm{N}$-doped multiwalled carbon nanotubes decorated with silver nanoparticles preserve cellular function. ACS Nano 2011, 5, 2458-2466. [CrossRef]

116. Aslan, S.; Deneufchatel, M.; Hashmi, S.; Li, N.; Pfefferle, L.D.; Elimelech, M.; Pauthe, E.; Van Tassel, P.R. Carbon nanotubebased antimicrobial biomaterials formed via layer-by-layer assembly with polypeptides. J. Colloid Interface Sci. 2012, 388, 268-273. [CrossRef]

117. Kavoosi, G.; Dadfar, S.M.M.; Dadfar, S.M.A.; Ahmadi, F.; Niakosari, M. Investigation of gelatin/multi-walled carbon nanotube nanocomposite films as packaging materials. Food Sci. Nutr. 2014, 2, 65-73. [CrossRef]

118. Gan, L.; Geng, A.; Jin, L.; Zhong, Q.; Wang, L.; Xu, L.; Mei, C. Antibacterial nanocomposite based on carbon nanotubes-silver nanoparticles-co-doped polylactic acid. Polym. Bull. 2020, 77, 793-804. [CrossRef]

119. Benigno, E.; Lorente, M.A.; Olmos, D.; González-Gaitano, G.; González-Benito, J. Nanocomposites based on low density polyethylene filled with carbon nanotubes prepared by high energy ball milling and their potential antibacterial activity. Polym. Int. 2019, 68, 1155-1163. [CrossRef]

120. Wang, W.; Zhu, L.; Shan, B.; Xie, C.; Liu, C.; Cui, F.; Li, G. Preparation and characterization of SLS-CNT/PES ultrafiltration membrane with antifouling and antibacterial properties. J. Membr. Sci. 2018, 548, 459-469. [CrossRef]

121. Pandiyan, R.; Mahalingam, S.; Ahn, Y.-H. Antibacterial and photocatalytic activity of hydrothermally synthesized SnO2 doped GO and CNT under visible light irradiation. J. Photochem. Photobiol. B Biol. 2019, 191, 18-25. [CrossRef]

122. Lakourj, M.M.; Norouzian, R.-S.; Esfandyar, M. Conducting nanocomposites of polypyrrole-co-polyindole doped with carboxylated CNT: Synthesis approach and anticorrosion/antibacterial/antioxidation property. Mater. Sci. Eng. B 2020, 261, 114673. [CrossRef]

123. Shaham, G.; Veisi, H.; Hekmati, M. Silver nanoparticle-decorated multi-walled carbon nanotube/pramipexole nanocomposite: Synthesis, characterization and application as an antibacterial agent. Appl. Organomet. Chem. 2017, 31, e3737. [CrossRef]

124. Baek, S.; Joo, S.H.; Su, C.; Toborek, M. Antibacterial effects of graphene-and carbon-nanotube-based nanohybrids on Escherichia coli: Implications for treating multidrug-resistant bacteria. J. Environ. Manag. 2019, 247, 214-223. [CrossRef] [PubMed]

125. Xu, Y.; Liu, J.; Xie, M.; Jing, L.; Xu, H.; She, X.; Li, H.; Xie, J. Construction of novel CNT/LaVO4 nanostructures for efficient antibiotic photodegradation. Chem. Eng. J. 2019, 357, 487-497. [CrossRef]

126. Palza, H.; Saldias, N.; Arriagada, P.; Palma, P.; Sanchez, J. Antibacterial carbon nanotubes by impregnation with copper nanostructures. JOM 2017, 69, 1319-1324. [CrossRef]

127. Joghataeian, M.; Bahari, A.; Qavami, A.; Raeisi, M.J. An antibacterial study of a new magnetic carbon nanotube/core-shell nanohybrids. J. Environ. Chem. Eng. 2020, 8, 104150. [CrossRef]

128. Sivaraj, D.; Vijayalakshmi, K. Preferential killing of bacterial cells by hybrid carbon nanotube-MnO2 nanocomposite synthesized by novel microwave assisted processing. Mater. Sci. Eng. C 2017, 81, 469-477. [CrossRef]

129. Ku, S.H.; Lee, M.; Park, C.B. Carbon-based nanomaterials for tissue engineering. Adv. Healthc. Mater. 2013, 2, 244-260. [CrossRef]

130. Goenka, S.; Sant, V.; Sant, S. Graphene-based nanomaterials for drug delivery and tissue engineering. J. Control. Release 2014, 173, 75-88. [CrossRef]

131. Gonzalez, A.C.; Costa, T.F.; Andrade, Z.A.; Medrado, A.R. Wound healing-A literature review. An. Bras. Dermatol. 2016, 91, 614-620. [CrossRef]

132. Robson, M.C.; Steed, D.L.; Franz, M.G. Wound healing: Biologic features and approaches to maximize healing trajectories. Curr. Probl. Surg. 2001, 38, 72-140. [CrossRef] 
133. Velnar, T.; Bailey, T.; Smrkolj, V. The wound healing process: An overview of the cellular and molecular mechanisms. J. Int. Med. Res. 2009, 37, 1528-1542. [CrossRef]

134. Natarajan, S.; Williamson, D.; Stiltz, A.J.; Harding, K. Advances in wound care and healing technology. Am. J. Clin. Dermatol. 2000, 1, 269-275. [CrossRef]

135. Junker, J.P.; Kamel, R.A.; Caterson, E.J.; Eriksson, E. Clinical impact upon wound healing and inflammation in moist, wet, and dry environments. Adv. Wound Care 2013, 2, 348-356. [CrossRef]

136. Zhao, R.; Liang, H.; Clarke, E.; Jackson, C.; Xue, M. Inflammation in chronic wounds. Int. J. Mol. Sci. 2016, 17, 2085. [CrossRef]

137. He, J.; Shi, M.; Liang, Y.; Guo, B. Conductive adhesive self-healing nanocomposite hydrogel wound dressing for photothermal therapy of infected full-thickness skin wounds. Chem. Eng. J. 2020, 394, 124888. [CrossRef]

138. Xu, M.; Li, Q.; Fang, Z.; Jin, M.; Zeng, Q.; Huang, G.; Jia, Y.-G.; Wang, L.; Chen, Y. Conductive and antimicrobial macroporous nanocomposite hydrogels generated from air-in-water Pickering emulsions for neural stem cell differentiation and skin wound healing. Biomater. Sci. 2020, 8, 6957-6968. [CrossRef]

139. Liang, N.; Wu, L.; Yang, Y. Multifunctional double network hydrogel film for skin wound healing. Mater. Express 2021, 11, 1084-1091. [CrossRef]

140. He, S.; Huang, J.; Zhang, Q.; Zhao, W.; Xu, Z.; Zhang, W. Bamboo-like nanozyme based on nitrogen-doped carbon nanotubes encapsulating cobalt nanoparticles for wound antibac-terial applications. Adv. Funct. Mater. 2021, 31, 2105198. [CrossRef]

141. Kittana, N.; Assali, M.; Abu-Rass, H.; Lutz, S.; Hindawi, R.; Ghannam, L.; Zakarneh, M.; Mousa, A. Enhancement of wound healing by single-wall/multi-wall carbon nanotubes complexed with chitosan. Int. J. Nanomed. 2018, 13, 7195-7206. [CrossRef]

142. Simpson, D.M.; Ross, R. The neutrophilic leukocyte in wound repair a study with antineutrophil serum. J. Clin. Investig. 1972, 51, 2009-2023. [CrossRef]

143. Diegelmann, R.F.; Evans, M.C. Wound healing: An overview of acute, fibrotic and delayed healing. Front. Biosci. J. Virtual Libr. 2004, 9, 283-289. [CrossRef] [PubMed]

144. Tocco, I.; Zavan, B.; Bassetto, F.; Vindigni, V. Nanotechnology-based therapies for skin wound regeneration. J. Nanomater. 2012, 2012, 714134. [CrossRef]

145. Gurtner, G.C.; Werner, S.; Barrandon, Y.; Longaker, M.T. Wound repair and regeneration. Nature 2008, 453, 314-321. [CrossRef] [PubMed]

146. Wang, L.; Hu, S.; Ullah, M.W.; Li, X.; Shi, Z.; Yang, G. Enhanced cell proliferation by electrical stimulation based on electroactive regenerated bacterial cellulose hydrogels. Carbohydr. Polym. 2020, 249, 116829. [CrossRef]

147. Omrani, M.M.; Ansari, M.; Kordestani, S.S.; Kiaie, N.; Salati, A. Enhanced bone marrow stem cell attachment and differentiation on PCL/CNT substrate. Inorg. Nano-Metal. Chem. 2019, 49, 136-142. [CrossRef]

148. Wang, S.; Li, Y.; Zhao, R.; Jin, T.; Zhang, L.; Li, X. Chitosan surface modified electrospun poly ( $\varepsilon$-caprolactone)/carbon nanotube composite fibers with enhanced mechanical, cell proliferation and antibacterial properties. Int. J. Biol. Macromol. 2017, 104, 708-715. [CrossRef]

149. Di Leo, N.; Battaglini, M.; Berger, L.; Giannaccini, M.; Dente, L.; Hampel, S.; Vittorio, O.; Cirillo, G.; Raffa, V. A catechin nanoformulation inhibits WM266 melanoma cell proliferation, migration and associated neo-angiogenesis. Eur. J. Pharm. Biopharm. 2017, 114, 1-10. [CrossRef]

150. Madhusoodan, A.; Das, K.; Mili, B.; Kumar, K.; Kumar, A.; Saxena, A.; Singh, P.; Dutt, T.; Bag, S. In vitro proliferation and differentiation of canine bone marrow derived mesenchymal stem cells over hydroxyl functionalized CNT substrates. Biotechnol. Rep. 2019, 24, e00387. [CrossRef]

151. Mombini, S.; Mohammadnejad, J.; Bakhshandeh, B.; Narmani, A.; Nourmohammadi, J.; Vahdat, S.; Zirak, S. Chitosan-PVACNT nanofibers as electrically conductive scaffolds for cardiovascular tissue engineering. Int. J. Biol. Macromol. 2019, 140, 278-287. [CrossRef]

152. Khan, A.; Hussain, A.; Sidra, L.; Sarfraz, Z.; Khalid, H.; Khan, M.; Manzoor, F.; Shahzadi, L.; Yar, M.; Rehman, I. Fabrication and in vivo evaluation of hydroxyapatite/carbon nanotube electrospun fibers for biomedical/dental application. Mater. Sci. Eng. C 2017, 80, 387-396. [CrossRef]

153. Lu, X.; Zhu, Y.; Bai, R.; Wu, Z.; Qian, W.; Yang, L.; Cai, R.; Yan, H.; Li, T.; Pandey, V. Long-term pulmonary exposure to multi-walled carbon nanotubes promotes breast cancer metastatic cascades. Nat. Nanotechnol. 2019, 14, 719-727. [CrossRef]

154. Shokraei, N.; Asadpour, S.; Shokraei, S.; Nasrollahzadeh Sabet, M.; Faridi-Majidi, R.; Ghanbari, H. Development of electrically conductive hybrid nanofibers based on CNT-polyurethane nanocomposite for cardiac tissue engineering. Microsc. Res. Tech. 2019, 82, 1316-1325. [CrossRef]

155. Kramer, N.; Walzl, A.; Unger, C.; Rosner, M.; Krupitza, G.; Hengstschläger, M.; Dolznig, H. In vitro cell migration and invasion assays. Mutat. Res. 2013, 752, 10-24. [CrossRef]

156. Liang, Y.; Zhao, X.; Hu, T.; Han, Y.; Guo, B. Mussel-inspired, antibacterial, conductive, antioxidant, injectable composite hydrogel wound dressing to promote the regeneration of infected skin. J. Colloid Interface Sci. 2019, 556, 514-528. [CrossRef] 